\title{
Intermetallic Compounds Synthesized by Mechanical Alloying for Solid-State Hydrogen Storage: A Review
}

\author{
Yuchen Liu*, Djafar Chabane (D) and Omar Elkedim (D) \\ FEMTO-ST Institute, University Bourgogne Franche-Comté, UTBM, CNRS, 90000 Belfort, France; \\ djafar.chabane@utbm.fr (D.C.); omar.elkedim@utbm.fr (O.E.) \\ * Correspondence: yuchen.liu@utbm.fr
}

Citation: Liu, Y.; Chabane, D.; Elkedim, O. Intermetallic Compounds Synthesized by Mechanical Alloying for Solid-State Hydrogen Storage: A Review. Energies 2021, 14, 5758. https:// doi.org/10.3390/en14185758

Academic Editor: Attilio Converti

Received: 3 August 2021

Accepted: 10 September 2021

Published: 13 September 2021

Publisher's Note: MDPI stays neutral with regard to jurisdictional claims in published maps and institutional affiliations.

Copyright: (c) 2020 by the authors. Licensee MDPI, Basel, Switzerland. This article is an open access article distributed under the terms and conditions of the Creative Commons Attribution (CC BY) license (https:// creativecommons.org/licenses/by/ $4.0 /)$.

\begin{abstract}
Hydrogen energy is a very attractive option in dealing with the existing energy crisis. For the development of a hydrogen energy economy, hydrogen storage technology must be improved to over the storage limitations. Compared with traditional hydrogen storage technology, the prospect of hydrogen storage materials is broader. Among all types of hydrogen storage materials, solid hydrogen storage materials are most promising and have the most safety security. Solid hydrogen storage materials include high surface area physical adsorption materials and interstitial and non-interstitial hydrides. Among them, interstitial hydrides, also called intermetallic hydrides, are hydrides formed by transition metals or their alloys. The main alloy types are $A_{2} B, A B, A B_{2}, A_{3}, A_{2} B_{7}, A_{5}$, and $B C C$. $\mathrm{A}$ is a hydride that easily forms metal (such as $\mathrm{Ti}, \mathrm{V}, \mathrm{Zr}$, and $\mathrm{Y}$ ), while $\mathrm{B}$ is a non-hydride forming metal (such as $\mathrm{Cr}, \mathrm{Mn}$, and $\mathrm{Fe}$ ). The development of intermetallic compounds as hydrogen storage materials is very attractive because their volumetric capacity is much higher $\left(80-160 \mathrm{kgH}_{2} \mathrm{~m}^{-3}\right)$ than the gaseous storage method and the liquid storage method in a cryogenic tank $\left(40\right.$ and $\left.71 \mathrm{kgH}_{2} \mathrm{~m}^{-3}\right)$. Additionally, for hydrogen absorption and desorption reactions, the environmental requirements are lower than that of physical adsorption materials (ultra-low temperature) and the simplicity of the procedure is higher than that of non-interstitial hydrogen storage materials (multiple steps and a complex catalyst). In addition, there are abundant raw materials and diverse ingredients. For the synthesis and optimization of intermetallic compounds, in addition to traditional melting methods, mechanical alloying is a very important synthesis method, which has a unique synthesis mechanism and advantages. This review focuses on the application of mechanical alloying methods in the field of solid hydrogen storage materials.
\end{abstract}

Keywords: mechanical alloying; intermetallic compounds; solid hydrogen storage

\section{Introduction}

Currently, as fossil energy is on the verge of disappearing [1] and pollution caused by fossil fuels is becoming more serious [2], it is urgent to develop clean energy. As an important type of clean energy, hydrogen $\left(\mathrm{H}_{2}\right)$ energy has the advantages of being nonpolluting, being easy to be produced, and having extremely high energy density. Compared with other clean energy sources, such as geothermal energy, wind energy, and tidal energy, it is the best choice. The utilization of $\mathrm{H}_{2}$ energy involves many aspects, such as the production, transportation, storage, and utilization of $\mathrm{H}_{2}$ energy. Among them, what restricts the use of $\mathrm{H}_{2}$ energy is the storage technology of $\mathrm{H}_{2}$ energy. The storage of $\mathrm{H}_{2}$ energy can be roughly divided into two types: physical storage methods and chemical storage methods.

Physical storage includes high-pressure compressed gas storage and ultra-low temperature storage. Compressed $\mathrm{H}_{2}$ requires high-pressure vessels to be loaded, and these vessels should be strong, light, and anti-explosive under special circumstances. Actually, the volume density of $\mathrm{H}_{2}$ increases with pressure, but the weight density decreases at the same time. Therefore, as the weight density in the compressed gas system decreases, 
improvements in the volume storage density are sacrificed. At the same time, the future pressure vessel is expected to consist of three layers: a polymer lining, a carbon fiber composite material (which is a stress-bearing component), and an outer aramid layer that can withstand mechanical and chemical damage [3]. This also drive the cost higher. In summary, although compressed gas $\mathrm{H}_{2}$ storage technology is simple and mature, lighter, safer, and low-cost containers still need to be researched. For ultra-low temperature liquid $\mathrm{H}_{2}$ storage, liquefaction and continuous evaporation of $\mathrm{H}_{2}$ require a relatively large amount of energy, which limits the application of liquid $\mathrm{H}_{2}$ storage in mobile equipment, such as vehicles. Liquid $\mathrm{H}_{2}$ storage is suitable for $\mathrm{H}_{2}$ in a relatively short period of time. Applications include being consumed, such as in the aerospace industry [4].

Chemical storage refers to the combination of $\mathrm{H}_{2}$ and materials through van der Waals forces or chemical bonds to store $\mathrm{H}_{2}$ in the $\mathrm{H}_{2}$ storage material in the form of atoms. This $\mathrm{H}_{2}$ storage method is the most attractive method because, for chemical $\mathrm{H}_{2}$ storage, reversible $\mathrm{H}_{2}$ absorption and desorption reactions can be carried out in a mild environment, and its $\mathrm{H}_{2}$ storage density is high, and there is no safety risk. There are many types of $\mathrm{H}_{2}$ storage materials, which can be divided into solid $\mathrm{H}_{2}$ storage materials and Liquid Organic $\mathrm{H}_{2}$ Carriers (LOHCs) according to their different material states.

The theoretical $\mathrm{H}_{2}$ storage capacity of $\mathrm{LOHCs}$ is extremely high, but the production of these liquid materials often requires extremely complicated steps, and a wide variety of catalysts are required to assist in the reaction when the reaction is at room temperature, so it is not suitable for the engines of vehicles; liquid materials are more suitable for $\mathrm{H}_{2}$ storage at fixed sites. Solid $\mathrm{H}_{2}$ storage materials are more reliable and safer than liquid and gaseous materials in ultra-low temperature storage [5].

Solid $\mathrm{H}_{2}$ storage materials can be divided into many types, such as intermetallic compounds, complex hydrides, chemical hydrides, etc. [6]. In this review, the focus is on intermetallic compounds.

In recent years, intermetallic compounds have attracted great attention because of their wide application in the development of $\mathrm{H}_{2}$ storage alloys [7]. There are many applications for intermetallic compounds, including $\mathrm{H}_{2}$ storage systems, Nickel Metal Hydride (NiMH) battery electrodes, $\mathrm{H}_{2}$ sensors and catalysts, and cooling systems [8]. Intermetallic compounds are attractive in the development of $\mathrm{H}_{2}$ storage alloys because they can absorb large amounts of $\mathrm{H}_{2}$. In addition, they are abundant and have diverse ingredients. Generally, $\mathrm{H}_{2}$ reacts with intermetallic compounds to produce a solid solution of $\mathrm{H}_{2}$ in the respective compound or the formed hydride. The hydride produced by the intermetallic compound is called the intermetallic hydride. The general formula is $A_{m} B_{n} H_{x}$. The interactions between metal atoms and interstitial $\mathrm{H}_{2}$ atoms determine its properties, so it largely depends on the crystal structure of the compound [9].

The materials used as solid-state $\mathrm{H}_{2}$ storage intermetallic compounds can be divided into $\mathrm{A}_{2} \mathrm{~B}, \mathrm{AB}, \mathrm{AB}_{2}, \mathrm{AB}_{3}, \mathrm{AB}_{5}$, and $\mathrm{BCC}$ according to their composition. According to the different main component, it can be divided into $\mathrm{Mg}$-based $\mathrm{H}_{2}$ storage alloy, Ti-based $\mathrm{H}_{2}$ storage alloy, $\mathrm{RE}$-based $\mathrm{H}_{2}$ storage alloy, etc.

$\mathrm{Mg}$ and $\mathrm{Mg}$-based alloys have long been considered potential $\mathrm{H}_{2}$ storage materials. Fifty years ago, scholars discovered that $\mathrm{Mg}$ metal and its alloys can be used as $\mathrm{H}_{2}$ storage materials. As a potential commercial $\mathrm{H}_{2}$ storage material, this material has some special advantages: (i) high abundance ( $2 \%$ of the composition of the surface of the Earth and almost unlimited in seawater), (ii) being non-toxic compared with other light elements and their hydrides that rapidly exothermic oxidation in the air, and (iii) being highly safe. In addition, the production technology of Magnesium $(\mathrm{Mg})$ is very mature, and the cost of raw materials is very low.

Research on the synthesis of hydride nanoparticles of $\mathrm{Mg}$ and $\mathrm{Mg}$-based alloys by the ball milling has been studied in depth. This method has a low cost, has a simple and convenient procedure, and is a technology that has been studied extensively by scholars. It is suitable for the synthesis of various low-particle-size powder materials and can even synthesize nanomaterials [10]. For $\mathrm{H}_{2}$ storage material synthesized by mechanical alloying, 
its particles have a nanometre diameter and, due to its higher specific surface area and larger number of defects, provide hydrogenation nucleation sites and shorter $\mathrm{H}_{2}$ diffusion distances. Therefore, a fine powder has better $\mathrm{H}_{2}$ reaction kinetics than big particles [11]. The effect of particle size on the absorption kinetics of $\mathrm{Mg}$-based $\mathrm{H}_{2}$ storage alloys was shown in [12].

As an active metal, there is always an oxide layer on the surface of $\mathrm{Mg}$. The activation process is to decompose the surface oxide layer that inhibits $\mathrm{H}_{2}$ absorption. This process is usually carried out at high temperatures. However, mechanical alloying methods can overcome these difficulties because the powder particles undergo severe plastic deformation during mechanical alloying. The oxide layer on the particle surface is then destroyed. Additionally, by synthesizing these alloys by mechanical alloying, the most significant improvement in hydrogenation/dehydration kinetics can be achieved [13]. A catalyst is usually needed to further accelerate the $\mathrm{H}_{2}$ and dehydrogenation kinetics of the alloy.

Some factors may restrict the hydrogenation kinetics of $\mathrm{Mg}$ and $\mathrm{Mg}$ alloys. These factors include (i) the formation of oxide layers on the surface that inhibits the penetration of $\mathrm{H}_{2}$ into the alloys [14], (ii) the slow dissociation rate of $\mathrm{H}_{2}$ molecules on the $\mathrm{Mg}$ surface, (iii) the low speed of the $\mathrm{MgH}_{2} / \mathrm{Mg}$ interface [15], and (iv) the slow diffusion of $\mathrm{H}_{2}$ through magnesium hydride [15]. Most of these factors can be solved by nanostructured Mg using mechanical alloying with the existing catalytic additives.

Titanium $\mathrm{H}_{2}$ storage alloys mainly include $\mathrm{TiMn}_{2}$ [16], $\mathrm{Ti}_{2} \mathrm{Ni}$ [17], TiFe, etc. The TiFe intermetallic compound and its doped derivatives are a potential $\mathrm{H}_{2}$ storage alloy because it is inexpensive and has a relatively high $\mathrm{H}_{2}$ storage capacity, about $1.8 \mathrm{wt} . \%$; rapidly absorbs and desorbs $\mathrm{H}_{2}$; moderates $\mathrm{H}_{2}$ absorption conditions; and has abundant reserves, so it has a very high potential as a $\mathrm{H}_{2}$ storage material [18]. The most common method of preparing TiFe is to melt the element mixture of Ti and Fe at high temperatures in an inert atmosphere and then to place it at 800 to $900{ }^{\circ} \mathrm{C}$ for a long time. The activation of TiFe obtained in this way requires a high-temperature heat treatment (about $400{ }^{\circ} \mathrm{C}$ ) under high vacuum conditions and high $\mathrm{H}_{2}$ pressure (about $5 \mathrm{MPa}$ ) [19]; at the same time, the materials are prone to poisoning. TiFe alloy also has many other shortcomings, that is, the poor absorption and desorption kinetics, the obvious lag of hydride formation and decomposition, and the sensitivity to gas impurities [20].

In the past 30 years, great efforts have been made to modify TiFe alloys, such as alloying with one or several elements to partially replace Fe or Ti; chemical surface modification; and mechanical alloying to reduce particle size or alloying with catalysts, additives and other methods. Surface modifications can catalyze the adsorption and dissociation of $\mathrm{H}_{2}$ molecules on the surface of the alloy by a certain transition metal or alloy deposited on the surface to promote the hydrogenation of the material or can use acids or alkalis to eliminate stable oxide layers. These methods also help to improve the anti-poisoning ability of TiFe [21]. The study by Edalati et al. showed that, through the process of High Pressure Torsion (HPT) [22,23] and Roll Groove (GR) [24], TiFe is activated after severe plastic deformation. TiFe samples activated by HPT and GR processes can absorb and release $\mathrm{H}_{2}$ even after being stored in the air for several months. The study on the activation mechanism of HPT-treated TiFe shows that various defects such as nanoparticle grain boundaries and micro-cracks are the pathways for $\mathrm{H}_{2}$ to pass through the oxide layer that hinders material transport on the surface. The main shortcoming of GR is that the sample is not easy to be fully activated immediately. The biggest disadvantage of the HPT process is that the sample amount is usually less than $1 \mathrm{~g}$ [25]. In order to expand the production of TiFe for $\mathrm{H}_{2}$ storage, it is necessary to develop another severe plastic deformation technology that improves activation. This technology must have simple procedures, low cost, and high efficiency in producing severe plastic deformation. Mechanical alloying may be the ideal technology.

RE-based $\mathrm{H}_{2}$ storage alloys can be divided into $\mathrm{AB}_{5}$ type alloys and superstructure alloys $\left(\mathrm{AB}_{3}, \mathrm{~A}_{2} \mathrm{~B}_{7}, \mathrm{~A}_{5} \mathrm{~B}_{19}, \mathrm{AB}_{4}\right.$, etc.) according to their compositions. $\mathrm{AB}_{5}$-type $\mathrm{H}_{2}$ storage alloy is one of the first $\mathrm{H}_{2}$ storage alloys discovered, and it has also been used as a 
commercial $\mathrm{H}_{2}$ storage alloy for a long time in nickel- $\mathrm{H}_{2}$ batteries. The $\mathrm{AB}_{5}$ type $\mathrm{H}_{2}$ storage alloy has good $\mathrm{H}_{2}$ storage performance. Its typical alloy is $\mathrm{LaNi}_{5}$, which was first developed in 1969 by the Philips laboratory in the Netherlands.

After discovering the $\mathrm{H}_{2}$ storage capacity of $\mathrm{AB}_{5}$ alloy [26], an important research area focused on the engineering application of these compounds [27]. However, the $\mathrm{AB}_{5}$ alloys used are synthesized by the high-temperature equilibrium method [28].

At the beginning of the $\mathrm{LaNi}_{5}$ study, it was found that the capacity of this alloy decreases significantly during the cycles. After 100 charge and discharge cycles, the capacity drops by $40 \%$, which also determines that pure $\mathrm{LaNi}_{5}$ is not suitable for battery applications. Microscopic studies have shown that, during the cycle, the alloy particles change from an initial size of 7 to $2 \mathrm{~mm}$ to fine powder after 25 cycles. This is caused by the repeated strain of the crystal lattice in the process of $\mathrm{H}_{2}$ absorption and desorption. The decrease in particle size leads to a longer exposure of the alloy surface to the electrolyte and increases in alloy corrosion due to the high affinity of $\mathrm{LaNi}_{5}$ for water. The needle-like crystals of $\mathrm{La}(\mathrm{OH})_{3}$ were detected by scanning transmission electron microscopy. During the continuous pulverization of $\mathrm{LaNi}_{5}$ particles, La atoms are thrown to the grain boundary, where $\mathrm{La}$ is oxidized to form $\mathrm{La}(\mathrm{OH})_{3}$. Therefore, the electrode is consumed by the corrosion reaction, and the $\mathrm{H}_{2}$ storage capacity is reduced [29].

Extensive research on $\mathrm{H}_{2}$ storage alloy $\mathrm{LaNi}_{5}$ is to partially replace $\mathrm{La}$ and $\mathrm{Ni}$ with other elements to reduce the volume expansion ratio of the alloy to its hydride [30]. The equilibrium pressure of the alloy can be reduced by introducing many elements: $\mathrm{Cr}, \mathrm{Co}, \mathrm{Cu}, \mathrm{Al}$, and $\mathrm{Mn}$, etc. [31].

At the beginning of this century, $\mathrm{RE}-$ magnesium-nickel (RE-Mg-Ni)-based $\mathrm{H}_{2}$ storage alloys gradually emerged. This type of alloy has a unique structure with a long-period one-dimensional superstructure, in which $\mathrm{AB}_{5}$ units $\left(\mathrm{CaCu}_{5}\right.$ type structure) and $\mathrm{A}_{2} \mathrm{~B}_{4}$ units (Laves type structure) are accumulated in a rhombus at a ratio of 1:1 along the c-axis. Kadir et al. [32] showed this structure. Due to its unique structure, this type of alloy has the advantages of a high capacity and a good activation performance. Therefore, this type of alloy is expected to make up for the shortcomings of the low discharge capacity of $\mathrm{AB}_{5}$ type alloys, which has become one of the research hotspots.

Mechanical alloying is a kind of "non-equilibrium processing" technology. Since Libowitz et al. [33] first reported the synthesis of a metal alloy hydride $\mathrm{ZrNiH}_{3}$ by mechanical alloying in 1958, this method has always been a research hotspots in the field of $\mathrm{H}_{2}$ storage material synthesis. Unlike traditional melting methods, mechanical alloying has some unique advantages. First, the mechanical alloying procedure is simple, has a low cost, and uses simple equipment. Second, under the heat of positive mixing, mechanical alloying can also alloy two metals and can synthesize metastable alloys, amorphous alloys, or quasicrystals, etc. This is to expand the scope of additives and to develop new $\mathrm{H}_{2}$ storage alloys to lay a good foundation, which is difficult to achieve using melting methods. Mechanical alloying can realize the nanometerization of the particle size, which often greatly improves the $\mathrm{H}_{2}$ storage performance of the alloy. However, this method also has some drawbacks, such as powder contamination, difficulty in precise control of the composition, etc.

After the metal or alloy undergoes the mechanical alloying process, the particle size and crystal grain size are greatly reduced while the micro-strain and lattice distortion in the crystal increase. This has a great impact on the $\mathrm{H}_{2}$ storage performance of the material, mainly in terms of absorption/desorption kinetics and thermodynamics [34,35] as well as $\mathrm{H}_{2}$ storage capacity. First, the micro-strain and lattice distortion act on thermodynamics and kinetics, which can reduce the temperature of $\mathrm{H}_{2}$ desorption, etc. Second, for kinetics, grain refinement reduces the diffusion distance, and micro-strain and distortion increase diffusion and reduce the apparent activation energy. Additionally, the free energy of the material after ball milling is increased, which is released in the subsequent heating recovery process. For the $\mathrm{H}_{2}$ storage capacity, in the $\mathrm{AB}, \mathrm{AB}_{5}$, and $\mathrm{AB}_{2}$ materials [36,37], a significant decrease in capacity was observed after ball milling, while the capacity of $\mathrm{Mg}_{2} \mathrm{Ni}$ and $\mathrm{Mg}$ 
materials did not change significantly [38]. The reason may be the formation of amorphous or disordered structure and the intervention of impurities.

This review focuses on the application of mechanical alloying in the synthesis of intermetallic compounds as solid-state $\mathrm{H}_{2}$ storage materials.

\section{Application of Mechanical Alloying in Mg-Based Hydrogen Storage Alloys}

Magnesium in the pure form can absorb up to $7.6 \mathrm{wt} . \%$ of $\mathrm{H}_{2}$ (above $400{ }^{\circ} \mathrm{C}$ ), but it has low stability and low $\mathrm{H}_{2}$ absorption/desorption kinetics [39]. Some known compounds, such as $\mathrm{Mg}-\mathrm{Ni}$ compounds, $\mathrm{Mg}-\mathrm{Fe}$ compounds, etc., seem to be possible alternatives to magnesium hydride. These materials sacrifice volume or mass $\mathrm{H}_{2}$ capacity to obtain a better balance of pressure, stability, or cost [40].

$\mathrm{Mg}-\mathrm{Ni}$ series alloys can form $\mathrm{MgNi}_{2}$ alloy and $\mathrm{Mg}_{2} \mathrm{Ni}$ alloy as well as the newly emerged $\mathrm{MgNi}$ alloy. Among them, $\mathrm{Mg}_{2} \mathrm{Ni}$ alloy form $\mathrm{Mg}_{2} \mathrm{NiH}_{4}$ after $\mathrm{H}_{2}$ absorption. The $\mathrm{H}_{2}$ content is $3.6 \mathrm{wt} . \%$, which is much higher than the commercial $\mathrm{H}_{2}$ storage alloy $\mathrm{LaNi}_{5}$, which has a $\mathrm{H}_{2}$ absorption of $1.4 \mathrm{wt}$.\%. This alloy also has good $\mathrm{H}_{2}$ absorption and desorption kinetics at low temperatures. The theoretical electrochemical capacity of $\mathrm{Mg}_{2} \mathrm{Ni}$ can reach $1000 \mathrm{mAh} / \mathrm{g}$. On the basis of binary alloys, researchers often add third elements such as $\mathrm{Fe}$, $\mathrm{Ti}$, $\mathrm{La}$, etc. into $\mathrm{Mg}-\mathrm{Ni}$ materials [41]. The addition of new elements changes the composition and content of the alloy phase and can also play a catalytic role, thus improving the $\mathrm{H}_{2}$ storage performance of the alloys. Due to the significant difference between the high vapor pressure of $\mathrm{Mg}$ and the different melting temperature of the constituent elements (melting temperature for $\mathrm{Mg}$ is $650{ }^{\circ} \mathrm{C}$, and that for $\mathrm{Ni}$ is $1452{ }^{\circ} \mathrm{C}$ ), it is difficult to produce $\mathrm{Mg}_{2} \mathrm{Ni}$ alloys through the traditional smelting method. The mechanical alloying technology can easily synthesize these alloys because it is a completely solid state reaction process. In 1995, Singh and Zaluski $[42,43]$ used mechanical alloying to produce $\mathrm{Mg}_{2} \mathrm{Ni}$. $\mathrm{Mg}_{2} \mathrm{Ni}$ prepared by mechanical alloying was found to be able to react with $\mathrm{H}_{2}$ at a relatively low temperature, even room temperature, while the alloy synthesized by the melting method requires a hydrogenation temperature of $250-350{ }^{\circ} \mathrm{C}$ and a pressure of $15-50$ bar [44]. The $\mathrm{H}_{2}$ absorption and desorption properties of some $\mathrm{Mg}-\mathrm{Ni}$-based alloys are listed in [45].

$\mathrm{N}$. Cui et al. [46] believe that the $\mathrm{Ni}$ in the $\mathrm{Mg}-\mathrm{Ni}$ alloy has high electrocatalytic activity for the $\mathrm{H}_{2}$ desorption reaction of the alloy in the alkaline solution. Cold welding occurs during the mechanical alloying process. During this period, $\mathrm{Ni}$ as the second phase is evenly distributed. The Ni particles on the surface of the $\mathrm{Mg}$ alloy are the electrocatalytic active centres of the $\mathrm{H}_{2}$ evolution reaction. This is because they can reduce the charge transfer resistance, resulting in a significant increase in electrochemical capacity. At the same time, the mechanical alloying reduces the particle size and increases defect density caused by crystallization, which can improve the diffusion of $\mathrm{H}_{2}$ in the alloy. The $\mathrm{Mg}$ and $\mathrm{Ni}$ powder in the mechanical alloying process is not only a mixture of two components but also a new composite system with evenly distributed electrocatalytic active centers, large interface, small particle size, and high reactivity due to high defect density. However, he also proposed that excessive grinding damages the crystal lattice and causes a sharp drop in electrochemical capacity.

L. Zaluski et al. [43] prepared a nano-sized $\mathrm{Mg}_{2} \mathrm{Ni}$ alloy using the mechanical alloying method under the conditions of a ball-to-alloy ratio of 5 and a grinding time of $60 \mathrm{~h}$. He found that the nanocrystalline $\mathrm{Mg}_{2} \mathrm{Ni}$ alloy synthesized by mechanical alloying showed better $\mathrm{H}_{2}$ adsorption performance than the alloy prepared by conventional methods and that the produced powder can easily absorb $\mathrm{H}_{2}$ without activation because the mechanically alloyed nanocrystalline produces many very active fresh surfaces in the ball milling process. Conventional polycrystalline $\mathrm{Mg}_{2} \mathrm{Ni}$ can react with $\mathrm{H}_{2}$ at a temperature higher than $250{ }^{\circ} \mathrm{C}$, while nanocrystalline $\mathrm{Mg}_{2} \mathrm{Ni}$ can also absorb $\mathrm{H}_{2}$ at a lower temperature (for example, at $200{ }^{\circ} \mathrm{C}$, which is below the structural transition temperature of $\mathrm{Mg}_{2} \mathrm{NiH}_{4}$ hydride). No activation is required. Pd can catalyze the $\mathrm{H}_{2}$ absorption kinetics of nanocrystalline $\mathrm{Mg}_{2} \mathrm{Ni}$ 
at $200{ }^{\circ} \mathrm{C}$. Nanocrystalline $\mathrm{Mg}_{2} \mathrm{Ni}$ with a small amount of $\mathrm{Pd}$ can absorb $\mathrm{H}_{2}$ even at room temperature, does not require activation, and has good kinetics.

The nanocrystalline $\mathrm{Mg}_{2} \mathrm{Ni}$ intermetallic compound formed by mechanically alloying $\mathrm{Mg}$ and $\mathrm{Mg}_{2} \mathrm{Ni}$ can quickly absorb $\mathrm{H}_{2}$ without activation. $\mathrm{Mg}+\mathrm{Mg}_{2} \mathrm{Ni}$ composites need to be activated, but their $\mathrm{H}_{2}$ absorption rate is faster than $\mathrm{Mg}_{2} \mathrm{Ni}$ at $150{ }^{\circ} \mathrm{C}$ and $12 \mathrm{bar}$, and the capacity is $4.2 \mathrm{wt} . \%$ [47]. Some other additive were also investigated [48-51].

The nanocrystalline and amorphous $\mathrm{MgNi}$ alloy prepared by mechanical alloying is also a potential alloy as a negative electrode for NiMH batteries. For example, after 10 hours of ball milling, the MgNi alloy had an initial discharge capacity of $522 \mathrm{mAh} / \mathrm{g}$ [52]. In addition, unlike traditional $\mathrm{AB}_{5}$ and $\mathrm{AB}_{2} \mathrm{H}_{2}$ storage materials, this $\mathrm{MgNi}$ alloy does not require any activation and absorbs $\mathrm{H}_{2}$ directly. They also have the advantages of being almost nontoxic and low cost. However, their $\mathrm{H}_{2}$ absorption and desorption kinetics still needs to be further improved, and the actual discharge capacity is difficult to reach its theoretical value. In addition, from the point of view of commercial applications, this alloy has poor cycle stability as a hydride electrode. For example, after only 20 charge and discharge cycles, the discharge capacity of the $\mathrm{MgNi}$ electrode decays by more than $70 \%$. Such cycle stability prevents $\mathrm{MgNi}$ from being used as a battery electrode, so it must be improved by other methods. The decrease in capacity is related to the irreversible corrosion of the alloy electrode by the $\mathrm{KOH}$ in the battery. This reaction forms a $\mathrm{Mg}(\mathrm{OH})_{2}$ layer [53-55] on the surface of particles. This not only consumes the alloy itself but also greatly increases the charge transfer resistance at the alloy/electrolyte interface and may hinder the diffusion of $\mathrm{H}_{2}$ into and out of the alloy body [56]. The pulverization of the alloy during the $\mathrm{H}_{2}$ absorption and desorption cycle exacerbates this harmful phenomenon because the pulverization produces a new active surface and thus forms new additional $\mathrm{Mg}(\mathrm{OH})_{2}$ layers after making contact with the electrolyte.

Mustafa Anik et al. [57] studied the electrochemical properties of $\mathrm{Mg}_{2} \mathrm{Ni}$ and $\mathrm{MgNi}$ synthesized by Mechanical Alloying (MA). The results showed that the charge and discharge capacity of $\mathrm{Mg}_{2} \mathrm{Ni}$ alloy increased sharply with the increase in grinding time within $40 \mathrm{~h}$. The capacity of the alloy for which the grinding time exceeds $40 \mathrm{~h}$ no longer increases. They also found that the electrochemical performance of $\mathrm{MgNi}$ is much better than that of $\mathrm{Mg}_{2} \mathrm{Ni}$, and the charge-discharge reversibility of the $\mathrm{Mg}_{2} \mathrm{Ni}$ alloy is very poor. The lower initial discharge capacity and cycle stability of the $\mathrm{Mg}_{2} \mathrm{Ni}$ alloy are not only due to the blocking effect of the $\mathrm{Mg}(\mathrm{OH})_{2}$ layer but also maybe owing to the highly irreversible reaction of the alloy. The author believes that the existence of free electrocatalytically active $\mathrm{Ni}$ particles on the surface of the MgNi particles is the main factor that promotes the $\mathrm{H}_{2}$ transfer reaction on the surface of the alloy.

Chiaki Iwakura et al. [58] dissolved $\mathrm{Ti}$ and $\mathrm{V}$ into $\mathrm{MgNi}$ alloy by mechanical alloying. They found that the two-element solid-solution amorphous $\mathrm{Mg}_{0.9} \mathrm{Ti}_{0.06} \mathrm{~V}_{0.04} \mathrm{Ni}$ alloy prepared from MA is better than the single-element solid-solution $\mathrm{Mg}_{0.9} \mathrm{Ti}_{0.1} \mathrm{Ni}$ or $\mathrm{Mg}_{0.9} \mathrm{~V}_{0.1} \mathrm{Ni}$ alloys show better cycle performance. The AES depth distribution shows that, after the charge-discharge cycle in an alkaline solution, the oxide layer on the surface of the $\mathrm{Mg}_{0.9} \mathrm{Ti}_{0.06} \mathrm{~V}_{0.04} \mathrm{Ni}$ alloy is thinner than the surface of the $\mathrm{Mg}_{0.9} \mathrm{Ti}_{0.1} \mathrm{Ni}$ or $\mathrm{Mg}_{0.9} \mathrm{~V}_{0.1} \mathrm{Ni}$ alloy. The XRD data show that a composite oxide layer composed of Ti and $\mathrm{V}$ species precipitates on the surface of the alloy particles, which may be the reason for the synergistic effect of the solid solution of the two elements to promote the charge-discharge cycle performance.

Stephane Ruggeri et al. [59] synthesized a MgNiTi ternary alloy by adding Ti through ball milling on the basis of $\mathrm{MgNi}$ alloy. It was found that the initial discharge capacity of $\mathrm{MgNi}_{0.95} \mathrm{Ti}_{0.05}(\mathrm{C} 1=575 \mathrm{mAh} / \mathrm{g})$ was significantly increased compared with the $\mathrm{MgNi}$ electrode $(\mathrm{C} 1=522 \mathrm{mAh} / \mathrm{g})$. The author believes that this promotion of initial discharge capacity may be related to the formation of a multi-phase structure. The initial discharge capacity of $\mathrm{Mg}_{0.5} \mathrm{Ti}_{0.5} \mathrm{Ni}$ is $338 \mathrm{mAh} / \mathrm{g}$, and after 10 cycles, the capacity stability is $75 \%$. This cycle life is better than that of the initial $\mathrm{MgNi}$ alloy. The improvement in cycle life seems to be attributed to the formation of $\mathrm{TiO}_{2}$ that limits the formation of $\mathrm{Mg}(\mathrm{OH})_{2}$ on the alloy surface. However, the corrosion resistance of the electrode still needs further enhancement. 
Jian-Jun Jiang et al. [60] believed that the modification of MgNi materials is very complicated. Substituting other elements for $\mathrm{Mg}$ does not significantly change its performance. Therefore, they used MA to synthesize amorphous MgNi alloy electrodes. He found that amorphous $\mathrm{MgNi}$ alloys do not require an additional activation process, and the mass transfer reaction largely depends on the oxide on the surface of the alloy particles, not on the electrode itself. The reaction rate is controlled by the film thickness. In the initial cycle, the film thickness is very low, so the electron exchange process is relatively smooth. In further charge and discharge cycles, the thickness of the oxide film increases and begins to hinder the transport of electrons. Additionally, this layer of film cannot provide an effective anti-corrosion effect due to its open structure. For the alloy electrode covered by the oxide film, the exchange current density greatly decreases as the thickness of the oxide film increases. Therefore, if this alloy electrode is used in a strong alkaline solution, surface modification must be considered to improve performance.

O Elkedim and L Huang et al. [61] researched the substitution of Mn and Ti in the $\mathrm{Mg}_{2} \mathrm{Ni}$ phase by first principles Density Functional Theory (DFT) calculations. The results show that the doping of Mn reduces the thermodynamic stability of $\mathrm{Mg}_{2} \mathrm{Ni}$. When Ti is doped into $\mathrm{Mg}_{2} \mathrm{Ni}$, with the increase in Ti content, the thermodynamic stability of $\mathrm{Mg}_{2} \mathrm{Ni}$ gradually decreases. That is, the doping of Ti and Mn can promote the thermodynamics of $\mathrm{H}_{2}$ release of $\mathrm{Mg}_{2} \mathrm{Ni}$.

Amirkhiz et al. [62] pointed out that the addition of Single Wall Carbon Nanotube (SWCNT) can be used as a grinding aid in mechanical alloying to prevent the powder from consolidating on the surface of the ball and the container. Yao et al. [63] also believed that carbon materials have high dispersibility and catalytic activity, so they can promote the mechanical alloying process of ductile metals to produce finer particles. They believed that SWCNT can penetrate the thin hydroxide layer on the surface of $\mathrm{MgH}_{2}$ and can act as a ' $\mathrm{H}_{2}$ pump' to move $\mathrm{H}_{2}$ atoms to the surface. Multiwall Carbon Nanotube (MWCNT) also has a similar function. L.W. Huang et al. [64] studied the effects of $\mathrm{Al}$ substitution and the addition of MWCNTs about their structure and electrochemical properties of $\mathrm{Mg}_{2} \mathrm{Ni}$ alloys. They found that the ground alloy particles showed smaller particle size, agglomeration and better dispersibility, indicating that MWCNT can act as a grinding aid. After ball milling, most MWCNTs retain their tubular structure. All ball milled alloys with additives show excellent activation properties. However, adding MWCNTs is difficult to enhance the cycle life of the electrode. On the one hand, the discharge capacity is improved by the refinement of alloy particles. On the other hand, due to the enhanced dispersibility, more alloy particle surfaces are exposed to the $\mathrm{KOH}$ solution, which weakens the corrosion resistance of the ball milled alloy.

Based on the high $\mathrm{H}_{2}$ capacity of $\mathrm{Mg}$ and certain Ti-based alloys, scholars have developed new compounds of $\mathrm{Mg}-\mathrm{Ti}-\mathrm{Ni}-\mathrm{Fe}$ alloys. Guo et al. [65] used mechanical alloying to synthesize $\mathrm{Mg}_{76} \mathrm{Ti}_{12} \mathrm{Fe}_{12-x} \mathrm{Ni}_{x}(x=0,4,8,12)$ alloy and studied the effect of ball milling time on the $\mathrm{H}_{2}$ storage performance of the alloy. The results show that increasing the grinding time up to 80 hours increases the amount of $\mathrm{Mg}$ amorphous phase, which reduces the $\mathrm{H}_{2}$ storage performance. They also compared the $\mathrm{H}_{2}$ storage performance of alloys of various compositions after grinding for 40 hours and found that the storage capacity of alloys doped with $\mathrm{Ni}$ and $\mathrm{Fe}$ at the same time is much higher than that of alloys doped with single elements. In addition, the $\mathrm{H}_{2}$ absorption plateau pressures of $\mathrm{Mg}_{76} \mathrm{Ti}_{12} \mathrm{Fe}_{8} \mathrm{Ni}_{4}$ and $\mathrm{Mg}_{76} \mathrm{Ti}_{12} \mathrm{Fe}_{4} \mathrm{Ni}_{8}$ are reduced. The author explains that this phenomenon is due to the simultaneous formation of $\mathrm{Mg}_{2} \mathrm{Ni}$ and NiTi phases during the mechanical alloying process. They also observed that, as the Ni content increases, the Fe content decreases and that the hysteresis between the $\mathrm{H}_{2}$ absorption and desorption curves gradually decreases.

Mechanical alloying has also been applied to the synthesis and optimization of some binary magnesium-rich intermetallic compounds, such as $\mathrm{LaMg}_{12}, \mathrm{La}_{2} \mathrm{Mg}_{17}$, etc. X. P. Gao et al. [66] used mechanical alloying to add $\mathrm{Ni}$ to the $\mathrm{LaMg}_{12}$ alloy and studied its electrochemical $\mathrm{H}_{2}$ storage performance. When the weight ratio of $\mathrm{LaMg}_{12}$ to $\mathrm{Ni}$ is $1: 3$, the maximum discharge capacity of the alloy can reach $1010 \mathrm{mAh} / \mathrm{g}$. However, its cy- 
cle performance needs to be further improved. Zhang Yanghuan et al. [67] synthesized $\mathrm{LaMg}_{11} \mathrm{Ni}+\mathrm{x}$ wt.\% $\mathrm{Ni}(\mathrm{x}=100,200)$ alloys by mechanical alloying and studied the gaseous and electrochemical $\mathrm{H}_{2}$ storage kinetics. They found that increasing the Ni content can improve the kinetics, which is attributed to the decrease in activation energy and enthalpy. The milling time also affects two kinetics; the gaseous $\mathrm{H}_{2}$ absorption kinetic and electrochemical kinetic have maximum values with the change in milling time. LI Xia et al. [68] put $\mathrm{Ni}$ and $\mathrm{La}_{2} \mathrm{Mg}_{17}$ alloy together for ball milling and obtained $\mathrm{La}_{2} \mathrm{Mg}_{17}-\mathrm{x}$ wt. $\% \mathrm{Ni}(\mathrm{x}=0$, $50,100,150$, and 200) alloy. They found that the increase in $\mathrm{Ni}$ increases the proportion of the amorphous phase. This leads to a decrease in $\mathrm{H}_{2}$ absorption capacity and cycle stability but an increase in discharge capacity. The $\mathrm{H}_{2}$ absorption capacity of $\mathrm{La}_{2} \mathrm{Mg}_{17}-50 \mathrm{wt} . \% \mathrm{Ni}$ is $5.796 \mathrm{wt} . \%$ (3 MPa), and the maximum discharge capacity is $353.1 \mathrm{mAh} / \mathrm{g}$.

MY Song et al. [69] believed that, under certain conditions, the nucleation process controls the hydrogenation and dehydrogenation reactions of $\mathrm{Mg}$, so nucleation can be promoted by creating a large number of defects, and shorten the $\mathrm{H}_{2}$ diffusion distance by reducing the particle size of $\mathrm{Mg}$ particles. Therefore, the hydrogenation and dehydrogenation kinetics of magnesium can be improved by mechanical alloying. This method generates many defect nuclei on the surface and/or inside of magnesium through severe plastic deformation or can be added by adding additives act as active sites for nucleation and, at the same time, greatly reduces the particle size of magnesium to shorten the diffusion distance. They also believe that mechanical alloying changes the rate control step of the hydrogenation reaction because it promotes the diffusion of $\mathrm{H}_{2}$, so the control step becomes the gas-phase mass transfer and the chemical adsorption of $\mathrm{H}_{2}$.

Some complex additives have also been applied to improve the $\mathrm{H}_{2}$ storage performance of pure Mg. Mykhaylo Lotoskyy et al. [70] found an outstanding effect of graphite and $\mathrm{TiH}_{2}$ adding to $\mathrm{Mg}$ by high-energy reactive ball milling. This composite can reversely absorb $6 \mathrm{wt} . \% \mathrm{H}_{2}$. The addition of graphite greatly increases the cycle stability of the material. The author believes that graphite not only reduces the recrystallization of particles during the cycle but also helps to further refine the particles. C Zhou et al. [71] studied the effects of $\mathrm{TiH}_{2}, \mathrm{TiMn}_{2}$, and VTiCr on the kinetics of $\mathrm{Mg}$ hydrogenation. They used ball milling to produce alloy powder. The results show that the cycle kinetics of the material with VTiCr is better. The author found that the cycle kinetics of the material is relatively good at $300{ }^{\circ} \mathrm{C}$ but that the kinetics deteriorates severely at low temperatures $\left(25-150^{\circ} \mathrm{C}\right)$. The author attributed it to the growth process of microscopic grains during the reaction. Pavel Rizo-Acosta et al. [72] reported the effect of Early Transition Metal (ETM) hydride $\left(\mathrm{ETMH}_{x}\right)$ as a catalyst on the performance of cycling $\mathrm{H}_{2}$ storage of $\mathrm{Mg}$. They used reactive ball milling to mix the hydrides of $\mathrm{Sc}, \mathrm{Y}, \mathrm{Ti}, \mathrm{Zr}, \mathrm{V}$, and $\mathrm{Nb}$ with $\mathrm{Mg}$ and found that the presence of $\mathrm{ETMH}_{x}$ is beneficial to the decomposition of $\mathrm{H}_{2}$ molecules. Later, due to the high diffusion coefficient, $\mathrm{H}$ can diffuse rapidly in $\mathrm{ETMH}_{x}$, resulting in The rapid nucleation of $\mathrm{MgH}_{2}$. For cycle life, $\mathrm{ETMH}_{x}$ can limit grain growth and improve structural stability. Among all of the additives studied, $\mathrm{TiH}_{2}$ has the best performance. The reversible $\mathrm{H}_{2}$ capacity for 20 cycles is $4.8 \mathrm{wt} . \%$.

\section{Ti-Based Hydrogen Storage Alloys}

In 2000, Chiang, C.H., et al. [73] studied the hydrogenation performances of $\mathrm{TiFe}, \mathrm{TiFe}_{2}$, and Ti during mechanical alloying in the $\mathrm{H}_{2}$ gas atmosphere. They found that, through reaction ball milling, TiFe can directly absorb $\mathrm{H}_{2}$ without activation. Single-phase $\mathrm{TiH}$ is produced during the mechanical alloying. In addition, $\mathrm{TiFe}_{1.924}$ can also be hydrogenated by mechanical alloying in $\mathrm{H}_{2}$ because the alloy decomposes to form $\mathrm{TiFeH}, \mathrm{TiH}$, and $\mathrm{Fe}$ during this process. Based on the hydrides of $\mathrm{Ti}, \mathrm{TiFe}$ and $\mathrm{TiFe}_{2}$ and the thermal stability of the product powder during the ball milling process, they proposed that the TiFe milling reaction in $\mathrm{H}_{2}$ includes four steps: (1) The particles are broken to produce a fresh surface. (2) The powder absorbs $\mathrm{H}_{2}$. (3) $\mathrm{H}_{2}$ supersaturates in the powder. (4) TiFeH decomposes into $\mathrm{TiH}$ and $\mathrm{Fe}$. 
The research results of Hoda Emami et al. [74] showed there exists a close relationship between the activation of TiFe alloy and its particle size. Annealed TiFe with a grain size of micrometers does not absorb $\mathrm{H}_{2}$. Rolled samples with submicron to micron grain sizes are partially activated. The samples processed by HPT have nano- to sub-micron grain sizes and are fully activated under $3 \mathrm{MPa} \mathrm{H}_{2}$ pressure. The ball-milled sample with a nanometer particle size is fully activated and absorbs $\mathrm{H}_{2}$ at a pressure as low as $1 \mathrm{MPa}$.

The results of the literature [75] also show that the grinding of TiFe alloy and the transformation of alloy particles to nanometer sizes greatly simplify the activation process. In 2012, V. Zadorozhnyi et al. [76] demonstrated the possibility of directly synthesizing nano-size TiFe by solid-state reaction method compounds from a single component Fe and Ti using a mechanical alloying method. They discovered the exothermic effect of TiFe during the mechanical alloying process and believed that it was caused by the accumulation of excessive internal energy in the form of defects during the synthesis process. This characteristic plays a crucial role in the powder compaction process after mechanical alloying. It enhances the adhesion of the powder particles, thus ensuring that they are more easily compressed into blocks. Their other experimental results [77] show that the compacted sample of TiFe powder synthesized by mechanical alloying maintains the $\mathrm{H}_{2}$ adsorption performance of powdered TiFe and still maintains a considerable capacity after 20 absorption-adsorption cycles. After the first absorption-absorption cycle, the TiFe sample that was not compacted by mechanical alloying was immediately destroyed. They proposed that the improved cycle stability of TiFe samples produced by ball milling can be attributed to the formation of a special microstructure that resembles a sponge and acts as a specific bridge between powder particles. The formation of these contact bridges may be due to the material accumulating a great amount of energy in the process of mechanical alloying.

Later, they proposed that, although the nanocrystalline state of the intermetallic compound formed by mechanical alloying plays a crucial role in the activation stage, it is not so important in the subsequent absorption-desorption cycle because of the lattice repetition caused by the reaction itself. Expansion and contraction also form nano-sized grains and introduce a large number of defects. Inui et al. [78] added the importance of lattice defects generated during the MA treatment of TiFe. This partially disordered structure leads to the expansion of the solid solution area in the pressure-compositionisotherm curve, the reduction of the plateau pressure, and it also makes it easier for $\mathrm{H}_{2}$ to enter the crystal grains.

They have conducted a lot of research on synthesizing TiFe by mechanical alloying and adding various elements for doping. They are doped with $\mathrm{Mg}$ and $\mathrm{S}, \mathrm{Co}$ and $\mathrm{Ni}$, and $\mathrm{Al}$ and $\mathrm{Cr}$. The concentrations of $\mathrm{Mg}$ and $\mathrm{S}$ are as high as 2 and 1 at.\%, respectively. These alloys $\mathrm{TiFe}+1 \% \mathrm{~S}$ and $\mathrm{TiFe}+2 \% \mathrm{Mg}$ show $0.6-0.7$ wt. $\%$ reversible $\mathrm{H}_{2}$ capacity. The S-containing alloy has a very simple activation procedure, namely heating to $100{ }^{\circ} \mathrm{C}$ in $\mathrm{H}_{2}$ and placing it for about 20 minutes [79]. The results of doping Co and Ni also showed that the content of the two elements is as high as 2 at. \%, for the mechanical alloying ones, and the extension of the $\mathrm{H}$ solid solution region and the reduction in the $(\alpha+\beta)$ plateau have been found [80]. Their work also showed the results of doping $\mathrm{Al}$ and $\mathrm{Cr}$. The concentrations of the two are 20 and 6 at.\%. Mechanical alloying doped $\mathrm{TiFe}+5 \% \mathrm{Al}$ and $\mathrm{TiFe}+4 \% \mathrm{Cr}$ showed an extremely simple activation procedure and a reversible $\mathrm{H}_{2}$ capacity of $0.7 \mathrm{wt} . \%$, and the alloys containing $\mathrm{Al}$ had a higher plateau pressure. Compared with unalloyed TiFe, the hysteresis was significantly reduced. This characteristic is related to the smaller lattice expansion when the $b$ hydride phase is formed. They also reported the data of TiFe-Mn, TiFe-Zr, and TiFe-Cu alloys produced by ball milling [81].

Liang et al. [82] listed some of the ball milling parameters and the corresponding $\mathrm{H}_{2}$ storage performance.

G. K. Sujan et al. [83] mentioned some problems in the preparation of TiFe powder by mechanical alloying in his review. The main disadvantage is that, for mechanical alloying, the raw material must be powder and the production cost of titanium powder is very high. 
Reducing the adhesion of powder on the container wall caused by cold welding is very important to ensure the output and quality of the product. The literatures use process control agents, mainly cyclohexane and benzene, to effectively reduce powder adhesion. Falcao et al. [84] developed an alternative way to produce nanocrystalline $\mathrm{TiFe}$, using $\mathrm{TiH}_{2}$ in the raw material instead of Ti powder, resulting in a higher yield of TiFe. Contamination during mechanical alloying (for example, carbides formed by organic grinding aids and chromium in stainless steel containers and balls) is also a serious problem.

Tohru Nobuki et al. [85] used a mechanical alloying method to quickly synthesize a TiNi alloy within $20 \mathrm{~min}$. They demonstrated through the cross section of the powder sticking to the grinding ball that the formation of the alloy occurs through the inter-diffusion between thin layers of co-laminated pure elements. The hydrogenation thermodynamics and kinetics of short-term mechanical alloying TiNi are similar to TiNi obtained by melting.

Z. Zhang et al. [86] used mechanical alloying to dope $\mathrm{Mg}$ into TiNi alloy to produce $\operatorname{TiMgNi}_{x}(x=0.1,0.5,1,2)$ alloy and studied its structure and $\mathrm{H}_{2}$ storage performance. The results show that the average discharge capacity decay of the samples is very low, less than $1.1 \%$ per cycle. Among all of the samples, TiMgNi showed the highest discharge capacity. The author believes that this is related to the $\mathrm{MgNi}$ amorphous phase. They have conducted a lot of research on this ternary alloy synthesized by mechanical alloying, including adding additive $[87,88]$ and its application in NiMH batteries [89]. They also used mechanical alloying to prepare alloy $\operatorname{TiMgNi}_{x}(x=0.2,0.4,0.6,0.8,1)$ samples with different $\mathrm{Ni}$ content and explored the effect of $\mathrm{Ni}$ content [88]. They found that, when the $\mathrm{Ni}$ content increases, the discharge capacity and activation performance of $\mathrm{TiMgNi}_{x}$ alloy increase linearly. Other researchers also explored the properties of $\mathrm{Ti}-\mathrm{Mg}-\mathrm{Ni}$ alloy produced by ball milling $[90,91]$.

B. Hosni et al. [92] synthesized $\mathrm{Ti}_{2} \mathrm{Ni}$ by mechanical alloying at room temperature, and studied its structure and $\mathrm{H}_{2}$ storage performance. The results show that the activation of the alloy is very simple, requiring only one charge and discharge cycle. As for the cycle life, with the temperature gradually increases, the electrochemical discharge capacity loss after several cycles increases. The maximum capacity increases with the increase in temperature, and at the same time, the corrosion current density decreases. The author believes that the decrease in the oxide surface layer caused this phenomenon. Additive can also be added into $\mathrm{Ti}_{2} \mathrm{Ni}$ by mechanical alloying [93].

Hailiang Chu et al. [94] used mechanical alloying to mix $\mathrm{Ti}_{0.9} \mathrm{Zr}_{0.2} \mathrm{Mn}_{1.5} \mathrm{Cr}_{0.3} \mathrm{~V}_{0.3}$ alloy based on $\mathrm{TiMn}_{2}$ with $\mathrm{LaNi}_{3.8} \mathrm{Mn}_{0.3} \mathrm{Al}_{0.4} \mathrm{Co}_{0.5}\left(\mathrm{AB}_{5}\right)$ and $\mathrm{La}_{0.7} \mathrm{Mg}_{0.25} \mathrm{Zr}_{0.05} \mathrm{Ni}_{2.975} \mathrm{Co}_{0.525}$ $\left(\mathrm{AB}_{3.5}\right)$ additives to study the structure and electrochemical performance. The addition of additives did not change the $\mathrm{AB}_{2}$ structure of the main body but significantly increased the electrochemical discharge capacity, reaching $310.4 \mathrm{mAh} / \mathrm{g}$ and $314.0 \mathrm{mAh} / \mathrm{g}$, respectively. The author believes that the $\mathrm{AB}_{3.5}$ alloy can reduce the charge transfer resistance and that the $\mathrm{AB}_{5}$ alloy can improve the $\mathrm{H}_{2}$ diffusion of the $\mathrm{AB}_{2}$ alloy. Myong JinChoi et al. [95] mixed $\mathrm{TiMn}_{2}$ and TiFe by the mechanical alloying method, then added different content of $\mathrm{Ni}$, and studied its electrochemical performance. The results show that the $\mathrm{H}_{2}$ absorption capacity of the $\mathrm{TiMn}_{0.9} \mathrm{Fe}_{0.55}$ composite alloy is about $0.9 \mathrm{wt} . \%$ and that the alloy containing $30 \mathrm{wt} . \% \mathrm{Ni}$ has the highest discharge capacity of $110 \mathrm{mAh} / \mathrm{g}$, and this value was maintained for 20 cycles. The author attributed the improvement in performance to $\mathrm{Ni}$ catalyzing the electrochemical reaction and at the same time improving the corrosion resistance of the alloy.

\section{RE-Based Hydrogen Storage Alloys}

\subsection{AB 5 Type Hydrogen Storage Alloy}

In 2001, G. Liang et al. [96] began to synthesize $\mathrm{LaNi}_{5}$ using two MA pathways. The first one is the mechanical alloying of La powder and Ni powder, and the second one is the mechanical milling of $\mathrm{LaH}$ with Ni. They all result in the formation of the $\alpha-\mathrm{LaNi}_{5}$ hydride phase. After testing, the $\mathrm{H}_{2}$ storage performance of the two types of $\mathrm{LaNi}_{5}$ is similar to that of the melted bulk $\mathrm{LaNi}_{5}$. Another disadvantage of the $\mathrm{AB}_{5}$ alloy is that it is susceptible to all kinds of pollution. Improving the toxicity resistance of $\mathrm{AB}_{5}$ alloy 
and its hydride is generally achieved through surface modification methods, which (i) provide surface catalytic activity for $\mathrm{H}_{2}$ dissociation/recombination and/or (ii) introduce catalytic active centers to protect the surface of the alloy, with the active center replacing the alloy and reacting with impurities [97]. The most effective way to form new catalytic active centers on the surface of $\mathrm{MH}$ is to introduce platinum group elements. At this time, mechanical alloying is a good introduction method [98].

KD Modibane et al. [99] introduced $\mathrm{Pd}$ into $\mathrm{AB}_{5}$ alloys by mechanical alloying combined with conventional electroless plating technology, with the composition being $[\mathrm{La}, \mathrm{Ce}, \mathrm{Pr}, \mathrm{Nd}][\mathrm{Ni}, \mathrm{Co}, \mathrm{Al}, \mathrm{Mn}]_{5}$, and studied the $\mathrm{H}_{2}$ absorption performance of $\mathrm{Pd}$ on the alloy and the impact of poisoning tolerance. The results show that the alloy with $1 \mathrm{wt} . \%$ Pd has the best $\mathrm{H}_{2}$ absorption kinetic performance.

\section{2. $A B_{3}$ and $A_{2} B_{7}$ Hydrogen Storage Alloy}

Kadir et al. [100] reported the study of a new type of ternary alloy, the general formula of which is $\mathrm{RMg}_{2} \mathrm{Ni}_{9}(\mathrm{R}=\mathrm{RE}, \mathrm{Ca}, \mathrm{Y}), \mathrm{PuNi}_{3}$-type structure. It has been found that some ternary alloys based on $\mathrm{R}-\mathrm{Mg}-\mathrm{Ni}$ can reversibly absorb/desorb $\mathrm{H}_{2}$ at $1.8-1.87 \mathrm{wt} . \%$ and are therefore considered potential candidates for $\mathrm{H}_{2}$ storage alloys [100]. However, its cycle stability and overall performance must be further improved.

Many scholars study high-capacity alloys with $\mathrm{AB}_{3}$ components (A: $\mathrm{RE}$ metals, $\mathrm{Mg}$, $\mathrm{Ca}$, etc.; $\mathrm{B}$ : transition metals) [101-103]. Most scholars synthesize $\mathrm{AB}_{3}$ alloy by melting method, but $\mathrm{MA}$ also has unique advantages in synthesizing $\mathrm{AB}_{3}$ alloy. For example, Hassen Jaafar et al. [104] successfully synthesized the $\mathrm{AB}_{3}$ alloy $\mathrm{LaMg}_{2} \mathrm{Ni}_{5} \mathrm{Al}_{4}$ using MA.

Mouna Elghali et al. [105] produced $\mathrm{AB}_{3}$ alloy according to the equation $A B_{5}+2 A B_{2}=3 A B_{3}$. They produced $\mathrm{LaZr}_{2} \mathrm{Mn}_{4} \mathrm{Ni}_{5}$. Due to the immiscibility of La and $\mathrm{Zr}$ elements, this compound cannot be obtained by melting methods. Therefore, mechanical alloying methods are used. It is found that the cell volume is increased compared with the $\mathrm{LaMg}_{2} \mathrm{Ni}_{9}$ alloy [105]. They also used the above methods to produce alloys such as $\mathrm{LaTi}_{2} \mathrm{Cr}_{4} \mathrm{Ni}_{5}$ [106], $\mathrm{LaZr}_{2} \mathrm{Cr}_{4} \mathrm{Ni}_{5}$ [107], and $\mathrm{CeTi}_{2} \mathrm{Cr}_{4} \mathrm{Ni}_{5}$ [108], with the results showing that these alloys have good reversibility, high discharge capacity, and a good cycle stability.

In the $\mathrm{AB}_{3}$ alloy, $\mathrm{Ca}$ and $\mathrm{Mg}$ can be used instead of $\mathrm{A}$. Such an alloy has a $\mathrm{H}_{2}$ storage capacity of about $1.9 \mathrm{wt} . \%$ and a discharge capacity of about $370 \mathrm{mAh} / \mathrm{g}$ [109]. $\mathrm{LaCaMgNi}$, compounds are always produced by smelting or sintering method. However, it is difficult to produce stoichiometric $\mathrm{LaCaMgNi}_{9}$ using melting technology due to the vapor pressures of $\mathrm{Ca}$ and $\mathrm{Mg}$ being very high, and it is very easy to evaporate during the melting process. Another difficulty is that $\mathrm{Ca}$ and $\mathrm{Mg}$ are easily contaminated by oxygen at high temperatures [110]. The use of mechanical alloying (MA) can avoid these difficulties. S. Chebab et al. [111] used MA to treat pure $\mathrm{La}, \mathrm{Ni}, \mathrm{Ca}$, and $\mathrm{Mg}$ powders for 30 hours, and the weight percent of this phase reached $67 \%$. This alloy can absorb $6 \mathrm{H} /$ f.u. of $\mathrm{H}_{2}$.

In the past few years, people have studied the possibility of $\mathrm{La}_{2} \mathrm{Ni}_{7}$ alloy as a $\mathrm{H}_{2}$ storage alloy because of its good $\mathrm{H}$ absorption capacity. However, the $\mathrm{La}_{2} \mathrm{Ni}_{7}$ phase is hindered by its poor cycle stability because of poor corrosion resistance [112]. Different RE elements are usually used to replace $\mathrm{La}$, while $\mathrm{Co}, \mathrm{Mn}, \mathrm{Al}$, and some other elements are used to replace $\mathrm{Ni}$ to improve the electrochemical properties of such alloy electrodes [113].

In the work of M. Balcerzak et al. [114], MA technology was used to manufacture $\mathrm{La}_{2} \mathrm{Ni}_{7}$ alloy, and then, $\mathrm{Mg}$ element was also incorporated to produce the ternary alloy $\mathrm{La}_{2-x} \mathrm{Mg}_{x} \mathrm{Ni}_{7}(x=0-1)$. It was found that the electrochemical and thermodynamic properties of this alloy increased with the rise content of $\mathrm{Mg}$, and the alloy with the best performance was $\mathrm{La}_{1.5} \mathrm{Mg}_{0.5} \mathrm{Ni}_{7}$. Ni element forms a film on the surface of the alloy particles, and the film is very dense, which can effectively protect the material from corrosion by strong alkaline solutions.

In their another work [115], they also synthesized $\mathrm{La}_{1.5-x} \mathrm{Pr}_{x} \mathrm{Mg}_{0.5} \mathrm{Ni}_{7}$ and $\mathrm{La}_{1.5-x} \mathrm{Nd}_{x}$ $\mathrm{Mg}_{0.5} \mathrm{Ni}_{7}$ alloys $(x=0,0.25,0.5,1)$ with MA. It was found that replacing La with $\mathrm{Pr}$ or $\mathrm{Nd}$ elements resulted in increased cycle stability of the alloy and optimized $\mathrm{H}_{2}$ absorption kinetics. 
Martyna Dymek et al. [116] also doped the above materials. La is partially replaced by $\mathrm{Mg}$ (5.6 at.\%) and $\mathrm{Ni}$ is partially replaced by Co. The doped material shows easy activation characteristics (maximum capacity is reached after the second cycle) and excellent $\mathrm{H}_{2}$ capacity ( $14 \%$ larger than Co-free materials). The exchange current density of the Comodified $\mathrm{La}_{1.5} \mathrm{Mg}_{0.5} \mathrm{Ni}_{7}$ alloy is increased by $15 \%$, and the $\mathrm{H}_{2}$ diffusivity is also improved.

Marek Nowak et al. [117] used MA to synthesize $\mathrm{La}_{1.5} \mathrm{Mg}_{0.5} \mathrm{Ni}_{7}$ alloy and doped $\mathrm{Al}$ or $\mathrm{Mn}$ into it. It is found that both elements can improve its $\mathrm{H}_{2}$ adsorption. The time required for the third cycle to reach $95 \%$ of the maximum $\mathrm{H}_{2}$ capacity was respectively reduced to 5 and 6 minutes and enhanced the stability of the discharge capacity.

\section{Body-Centered Cubic (BCC) Alloys}

In addition to the abovementioned $\mathrm{H}_{2}$ storage alloys that have been extensively studied, MA can also be used in the synthesis and performance optimization of BCC structure $\mathrm{H}_{2}$ storage alloys.

Y.Q. Hu et al. [118] used mechanical alloying to synthesize $\mathrm{TiCr}_{2}$ with BCC structure and compared the performance with the alloy of the same composition produced by mechanical grinding. They found that the overall performance of the alloy produced by mechanical alloying is better than that of the mechanically crushed alloy. The $\mathrm{H}_{2}$ absorption capacity of the MA sample is $1.0 \mathrm{wt} . \%\left(52{ }^{\circ} \mathrm{C}, 2.5 \mathrm{MPa}\right)$, and the desorption capacity is $0.6 \mathrm{wt} . \%$. Nobuhiko Takeichi et al. [119] studied the effect of different $\mathrm{Cr}$ content on the performance of $\mathrm{TiCr}_{2-x}(x$ $=0,0.2$ and 0.5). The results show that the sample can react with $\mathrm{H}_{2}$ under the conditions of $5 \mathrm{MPa}$ and $250{ }^{\circ} \mathrm{C}$. $\mathrm{TiCr}_{1.5}$ has the highest $\mathrm{H}_{2}$ content, reaching $0.47 \mathrm{H} / \mathrm{M}\left(40^{\circ} \mathrm{C}, 8 \mathrm{MPa}\right)$

Compared with other intermetallic compounds, the V-rich solid solution with BCC structure has attracted great attention because of its relatively high $\mathrm{H}_{2}$ storage capacity (up to $4 \mathrm{wt} . \%)$ [120]. The volumetric $\mathrm{H}_{2}$ storage capacity of the $\mathrm{BCC}$ phase $\left(\mathrm{VH}_{2}\right.$ is $\left.0.16 \mathrm{~g} / \mathrm{cm}^{3}\right)$ exceeds that of liquid $\mathrm{H}_{2}\left(0.07 \mathrm{~g} / \mathrm{cm}^{3}\right)$ [121]. In addition, due to their high reactivity, V-BCC alloys can absorb $\mathrm{H}_{2}$ at relatively low temperatures without catalysts.

M. Balcerzak et al. [120] synthesized the V-based BCC solid solution $\mathrm{Ti}_{0.5} \mathrm{~V}_{1.4-x} \mathrm{Ni}_{0.1} \mathrm{Cr}_{x}$ $(x=0,0.1,0.2,0.3)$ using mechanical alloying, studied its structure and electronic properties, and studied the addition of $\mathrm{Cr}$ atom pairs The effect of vanadium-rich body core-alloy on $\mathrm{H}_{2}$ storage performance. X-ray photoelectron spectroscopy measurements show that the addition of $\mathrm{Cr}$ has a significant impact on the oxidation resistance of V-BCC alloys. The cyclic charge and discharge method proves that the Cr-doped V-BCC alloy significantly improves the cycle life of the material stability.

They also synthesized $\mathrm{Ti}_{0.5} \mathrm{~V}_{1.5-x} \mathrm{Mn}_{x}(x=0,0.1,0.2,0.3)$ [120], $\mathrm{Ti}_{0.5} \mathrm{~V}_{1.5-x} \mathrm{Ni}_{x}(x=0$, $0.1,0.2,0.3)[122]$ by mechanical alloying.

$\mathrm{Ti}_{0.5} \mathrm{~V}_{1.5-x} \mathrm{Co}_{x}$ and $\mathrm{Ti}_{0.5} \mathrm{~V}_{1.4-} \mathrm{Ni}_{0.1} \mathrm{Co}_{x}(x=0,0.1,0.2,0.3)$ [123] solid solutions synthesized by mechanical alloying can absorb $\mathrm{H}_{2}$ with no activation. Their $\mathrm{H}_{2}$ storage capacities decrease as $\mathrm{Co}$ atoms number increases. However, Co raises the hydrogenation kinetics, lowers the hysteresis, and improves the reversibility of the $\mathrm{H}_{2}$ adsorption.

Toshihiko Kondo et al. [124] mechanically alloyed $\mathrm{CaMg}_{2}$ with $\mathrm{V}$ and synthesized $\mathrm{Mg}_{2} \mathrm{CaV}_{3}$ ternary $\mathrm{BCC}$ alloy. This alloy is activated by graphite grinding and then can reach a $\mathrm{H}_{2}$ storage capacity of $3.3 \mathrm{wt} . \%(10 \mathrm{~h})$ at $25^{\circ} \mathrm{C}$. Unlike the classic V-based BCC alloy, the alloy still maintains the $\mathrm{BCC}$ structure after hydrogenation. The desorption process starts at $270{ }^{\circ} \mathrm{C}$ and $0.1 \mathrm{MPa}$ argon atmosphere.

Huaiyu Shao et al. [125] synthesized the Mg-based BCC alloy $\mathrm{Mg}_{60} \mathrm{Ni}_{5} \mathrm{Co}_{m} \mathrm{X}_{35-m}(\mathrm{X}$ $=\mathrm{Co}, \mathrm{B}, \mathrm{Al}, \mathrm{Cr}, \mathrm{V}, \mathrm{Pd}$, and $\mathrm{Cu}$ ) using the mechanical alloying method and studied the relationship between its lattice parameters and $\mathrm{H}_{2}$ absorption performance. The results show that the alloys with lattice parameters in the range of $0.300-0.308 \mathrm{~nm}$ absorb more $\mathrm{H}_{2}$ while the alloys with lattice parameters greater than $0.313 \mathrm{~nm}$ have difficulty in absorbing $\mathrm{H}_{2}$. The geometric effect is one of the main influencing factors.

The details of the $\mathrm{H}_{2}$ storage performance of the intermetallic compounds synthesized by mechanical alloying for $\mathrm{H}_{2}$ storage in the past five years are listed in Table 1 . The literature [126] shows the thermodynamic data of some materials. 
Table 1. $\mathrm{H}_{2}$ absorption/desorption properties of intermetallic compounds produced by mechanical alloying in the last 5 years.

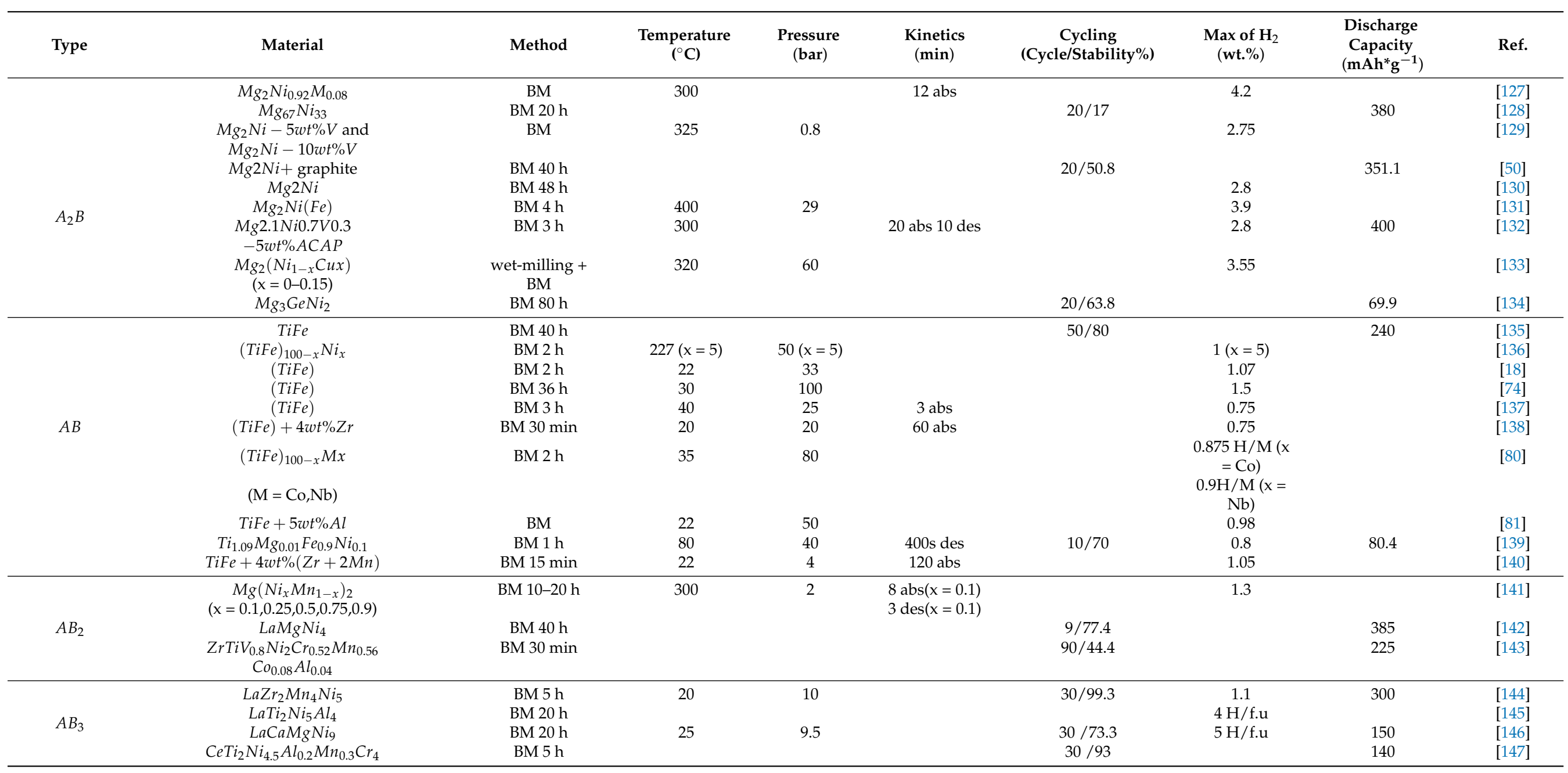


Table 1. Cont.

\begin{tabular}{|c|c|c|c|c|c|c|c|c|c|}
\hline Type & Material & Method & $\begin{array}{l}\text { Temperature } \\
\left({ }^{\circ} \mathrm{C}\right)\end{array}$ & $\begin{array}{l}\text { Pressure } \\
\quad(\text { bar })\end{array}$ & $\begin{array}{l}\text { Kinetics } \\
(\text { min })\end{array}$ & $\begin{array}{c}\text { Cycling } \\
\text { (Cycle/Stability\%) }\end{array}$ & $\begin{array}{l}\text { Max of } \mathrm{H}_{2} \\
\quad(\text { wt. } \%)\end{array}$ & $\begin{array}{l}\text { Discharge } \\
\text { Capacity } \\
\left(\mathbf{m A h}^{*} \mathbf{g}^{-1}\right)\end{array}$ & Ref. \\
\hline \multirow{3}{*}{$A_{2} B_{7}$} & $\begin{array}{l}L a_{1.5-x} G d_{x} M g_{0} .5 N i_{7} \\
\quad(0 \leqslant x \leqslant 1.5)\end{array}$ & & & 16 & $4 \mathrm{abs}$ & $\begin{array}{l}50 / 65(x=0.25) \\
50 / 94.9(x=0.5)\end{array}$ & $1.48(x=0.25)$ & $304(x=0.25)$ & [148] \\
\hline & $\mathrm{La}_{1.5} \mathrm{Mg}_{0.5} \mathrm{Ni}_{7}+\mathrm{Ni}-\mathrm{P}$ & BM $48 \mathrm{~h}$ & & & & $60 / 89.3$ & & 280 & [149] \\
\hline & $\begin{array}{c}L a 2-x M g x N i 7 \\
(\mathrm{x}=0: 0.25: 1)\end{array}$ & $\mathrm{BM} 48 \mathrm{~h}$ & 30 & 1000 & 2 des & $50 / 60$ & $1.53(x=0.5)$ & 248 & [114] \\
\hline \multirow{4}{*}{$A B_{5}$} & $\begin{array}{l}\mathrm{LaNi}_{3-x} \mathrm{Mn}_{x} \mathrm{Cr} r_{2} \\
(\mathrm{x}=0,0.1,0.3)\end{array}$ & BM $10 \mathrm{~h}$ & & & 4 & $30 / 90$ & & $300(x=0.3)$ & [150] \\
\hline & $M m N i_{5}$ & BM $1 \mathrm{~h}$ & 27 & 70 & $2 \mathrm{abs}$ & & 1.5 & & [151] \\
\hline & $\mathrm{CaNi} i_{4.8} \mathrm{Mn} n_{0.2}$ & BM $40 \mathrm{~h}$ & & & & $50 / 61$ & & 96 & [152] \\
\hline & $\mathrm{LaNi}_{5}-\mathrm{MWCNTs}$ & $\mathrm{BM}$ & 25 & 40 & & & 1.53 & & [153] \\
\hline \multirow{6}{*}{$\mathrm{BCC}$} & $\mathrm{Mg}_{55} \mathrm{Co}_{45}$ & BM $125 \mathrm{~h}$ & -15 & 100 & & & 3.24 & & [154] \\
\hline & $\mathrm{MgVCr}$ & BM 100 min & 30 & 60 & & & 0.9 & & [155] \\
\hline & $T i_{0.5} V_{1.4} C r_{0.1}$ & BM $14 \mathrm{~h}$ & 30 & & & $50 / 71.43$ & 2.9 & 70 & [156] \\
\hline & $\mathrm{Mg}_{64} \mathrm{Pd}_{3} \mathrm{Co}_{33}$ & BM $120 \mathrm{~h}$ & & & & $20 / 8$ & & 624 & [157] \\
\hline & $\mathrm{Ti}_{0.5} \mathrm{~V}_{1.3} \mathrm{Ni}_{0.1} \mathrm{Co}_{0.1}$ & BM $14 \mathrm{~h}$ & 30 & & & $50 / 50$ & & 75 & [123] \\
\hline & $T i_{0.7} N b_{0.3}$ & BM $6 \mathrm{~h}$ & 300 & 20 & & & 3.2 & & [158] \\
\hline
\end{tabular}




\section{Conclusions}

As a pure solid-state synthesis method, mechanical alloying has many applications in the synthesis and optimization of $\mathrm{H}_{2}$ storage materials. For different alloy systems, the specific effects of mechanical alloying are different. However, in general, mechanical alloying can reduce the particle size (even down to the nanometer scale), can increase the specific surface area, and can reduce the diffusion distance of $\mathrm{H}_{2}$. For some elements that cannot form a solid solution or alloy for various reasons, mechanical alloying makes the alloying of these elements possible because it is a pure solid-state method. This is not only a unique advantage compared to traditional melting but also an important basis for the synthesis of new $\mathrm{H}_{2}$ storage alloys and the addition of various additives to optimize performance. However, many scholars have also proposed mechanical alloying defects, the most important of which is the consolidation of the powder on the inner wall of the container and the surface of the ball. This causes an uneven composition, waste of raw materials, etc., and more importantly, it is difficult to finely control the composition of the material. Several methods have been proposed, such as adding grinding aids (carbon material, etc.) and grinding aid liquids (such as alcohol, etc.), but they still cannot be completely resolved. Mechanical alloying is also a problem without uniform parameters for each alloy system. Before performing mechanical alloying, various scholars or organizations usually conduct a series of experiments to determine the optimal parameters, but this not only consumes a lot of time and materials but may only obtained the best within the set parameter range.

In summary, for solid $\mathrm{H}_{2}$ storage materials, mechanical alloying is an extremely attractive synthesis method. Many scholars have used this method to synthesize $\mathrm{H}_{2}$ storage materials with great potential. However, for possible large-scale commercial applications in the future, further optimization of the technology still needs to be considered.

Author Contributions: Supervision, O.E., D.C. and Y.L.; Validation, O.E. and D.C.; Writing-Original draft, Y.L., D.C. and O.E.; Writing-Review and editing, Y.L., D.C. and O.E. All authors have read and agreed to the published version of the manuscript.

Funding: This research received no external funding.

Institutional Review Board Statement: Not applicable.

Informed Consent Statement: Not applicable.

Data Availability Statement: Not applicable.

Acknowledgments: The authors of the paper would like to thank the China Scholarship Council(CSC).

Conflicts of Interest: The authors declare no conflict of interest.

$\begin{array}{ll}\text { Abbreviations } \\ \text { The following abbreviations are used in this manuscript: } \\ \mathrm{H}_{2} \quad \text { Hydrogen } \\ \text { LOHCs } & \text { Liquid Organic Hydrogen Carriers } \\ \text { NiMH } & \text { Nickel Metal Hydride } \\ \text { RE } & \text { Rare Earth } \\ \text { Mg } & \text { Magnesium } \\ \text { HPT } & \text { High Pressure Torsion } \\ \text { GR } & \text { Roll Groove } \\ \text { HER } & \text { Hydrogen Evolution Reaction } \\ \text { DFT } & \text { Density Function Theory } \\ \text { SWCNT } & \text { Single Wall Carbon Nanotube } \\ \text { MWCNT } & \text { Multiwall Carbon Nanotube } \\ \text { ETM } & \text { Early Transition Metal } \\ \text { MH } & \text { Metal Hydride } \\ \text { MA } & \text { Mechanical Alloying } \\ \text { BCC } & \text { Body Centered Cubic }\end{array}$




\section{References}

1. Shafiee, S.; Topal, E. When will fossil fuel reserves be diminished? Energy Policy 2009, 37, 181-189. [CrossRef]

2. Vohra, K.; Vodonos, A.; Schwartz, J.; Marais, E.A.; Sulprizio, M.P.; Mickley, L.J. Global mortality from outdoor fine particle pollution generated by fossil fuel combustion: Results from GEOS-Chem. Environ. Res. 2021, 195, 110754. [CrossRef]

3. Park, G.; Jang, H.; Kim, C. Design of composite layer and liner for structure safety of hydrogen pressure vessel (type 4). J. Mech. Sci. Technol. 2021, 1-11. [CrossRef]

4. Züttel, A. Hydrogen storage methods. Naturwissenschaften 2004, 91, 157-172. [CrossRef] [PubMed]

5. Mahendra Y.; Xu, Q. Liquid-phase chemical hydrogen storage materials. Energy Environ. Sci. 2012, 5, 9698-9725. [CrossRef]

6. Rusman, N.A.; Dahari, M. A review on the current progress of metal hydrides material for solid-state hydrogen storage applications. Int. J. Hydrog. Energy 2016, 41, 12108-12126. [CrossRef]

7. Gasiorowski, A.; Iwasieczko, W.; Skoryna, D.; Drulis, H.; Jurczyk, M. Hydriding properties of nanocrystalline $\mathrm{Mg}_{2}-\mathrm{xMxNi}_{\mathrm{N}}$ alloys synthesized by mechanical alloying ( $\mathrm{M}=\mathrm{Mn}, \mathrm{Al})$. J. Alloys Compd. 2004, 364, 283-288. [CrossRef]

8. Falahati, H.; Barz, D.P. Evaluation of hydrogen sorption models for $\mathrm{AB}_{5}$-type metal alloys by employing a gravimetric technique. Int. J. Hydrog. Energy 2013, 38, 8838-8851. [CrossRef]

9. Palewski, T.; Tristan, N.V.; Drulis, H.; Ćwik, J. Hydrogenation process of the $\mathrm{Gd}_{3} \mathrm{M}(\mathrm{M}=\mathrm{Ni}$ or Co) intermetallics compound. J. Alloys Compd. 2005, 404-406, 584-587. [CrossRef]

10. Bhuyan, R.K.; Mohapatra, R.K.; Nath, G.; Sahoo, B.K.; Das, D.; Pamu, D. Influence of high-energy ball milling on structural, microstructural, and optical properties of $\mathrm{Mg}_{2} \mathrm{TiO}_{4}$ nanoparticles. J. Mater. Sci. Mater. Electron. 2019, 31, 628-636. [CrossRef]

11. Xie, X.B.; Hou, C.; Chen, C.; Sun, X.; Pang, Y.; Zhang, Y.; Yu, R.; Wang, B.; Du, W. First-principles studies in Mg-based hydrogen storage Materials: A review. Energy 2020, 211, 118959. [CrossRef]

12. Luo, Q.; Li, J.; Li, B.; Liu, B.; Shao, H.; Li, Q. Kinetics in Mg-based hydrogen storage materials: Enhancement and mechanism. J. Magnes. Alloy. 2019, 7, 58-71. [CrossRef]

13. Jurczyk, M.; Smardz, L.; Okonska, I.; Jankowska, E.; Nowak, M.; Smardz, K. Nanoscale Mg-based materials for hydrogen storage. Int. J. Hydrog. Energy 2008, 33, 374-380. [CrossRef]

14. Khan, D.; Panda, S.; Ma, Z.; Ding, W.; Zou, J. Formation and hydrogen storage behavior of nanostructured $\mathrm{Mg}_{2} \mathrm{FeH}_{6}$ in a compressed 2MgH2-Fe composite. Int. J. Hydrog. Energy 2020, 45, 21676-21686. [CrossRef]

15. Antiqueira, F.J.; Leiva, D.R.; Zepon, G.; de Cunha, B.F.; Figueroa, S.J.; Botta, W.J. Fast hydrogen absorption/desorption kinetics in reactive milled Mg-8 mol\% Fe nanocomposites. Int. J. Hydrog. Energy 2020, 45, 12408-12418. [CrossRef]

16. Liu, B.H.; Kim, D.M.; Lee, K.Y.; Lee, J.Y. Hydrogen storage properties of TiMn2-based alloys. J. Alloys Compd. 1996, 240, $214-218$. [CrossRef]

17. Hosni, B.; Khaldi, C.; ElKedim, O.; Fenineche, N.; Lamloumi, J. Electrochemical properties of $\mathrm{Ti}_{2} \mathrm{Ni}$ hydrogen storage alloy. Int. J. Hydrog. Energy 2017, 42, 1420-1428. [CrossRef]

18. Zadorozhnyy, V.Y.; Milovzorov, G.S.; Klyamkin, S.N.; Zadorozhnyy, M.Y.; Strugova, D.V.; Gorshenkov, M.V.; Kaloshkin, S.D. Preparation and hydrogen storage properties of nanocrystalline TiFe synthesized by mechanical alloying. Prog. Nat. Sci. Mater. Int. 2017, 27, 149-155. [CrossRef]

19. Reilly, J.J.; Wiswall, R.H. Formation and properties of iron titanium hydride. Inorg. Chem. 1974, 13, 218-222. [CrossRef]

20. Sandrock, G.D.; Goodell, P.D. Surface poisoning of $\mathrm{LaNi}_{5}, \mathrm{FeTi}$ and (Fe,Mn)Ti by $\mathrm{O}_{2}, \mathrm{Co}$ and $\mathrm{H}_{2} \mathrm{O}$. J. Less Common Met. 1980, 73, 161-168. [CrossRef]

21. Davids, M.W.; Lototskyy, M.; Nechaev, A.; Naidoo, Q.; Williams, M.; Klochko, Y. Surface modification of TiFe hydrogen storage alloy by metal-organic chemical vapour deposition of palladium. Int. J. Hydrog. Energy 2011, 36, 9743-9750. [CrossRef]

22. Edalati, K.; Matsuda, J.; Iwaoka, H.; Toh, S.; Akiba, E.; Horita, Z. High-pressure torsion of TiFe intermetallics for activation of hydrogen storage at room temperature with heterogeneous nanostructure. Int. J. Hydrog. Energy 2013, 38, 4622-4627. [CrossRef]

23. Edalati, K.; Matsuda, J.; Arita, M.; Daio, T.; Akiba, E.; Horita, Z. Mechanism of activation of TiFe intermetallics for hydrogen storage by severe plastic deformation using high-pressure torsion. Appl. Phys. Lett. 2013, 103, 143902. [CrossRef]

24. Edalati, K.; Matsuda, J.; Yanagida, A.; Akiba, E.; Horita, Z. Activation of TiFe for hydrogen storage by plastic deformation using groove rolling and high-pressure torsion: Similarities and differences. Int. J. Hydrog. Energy 2014, 39, 15589-15594. [CrossRef]

25. Valiev, R.Z.; Estrin, Y.; Horita, Z.; Langdon, T.G.; Zechetbauer, M.J.; Zhu, Y.T. Producing bulk ultrafine-grained materials by severe plastic deformation. JOM 2006, 58, 33-39. [CrossRef]

26. Vucht, J.V.; Kuijpers, F.; Bruning, H.C.A.M. Reversible room-temperature absorption of large quantities of hydrogen by intermetallic compounds. Philips Res. Rep. 1970, 25, 133-140.

27. Huston, E.L.; Sandrock, G.D. Engineering properties of metal hydrides. J. Less Common Met. 1980, 74, 435-443. [CrossRef]

28. Kim, J.K.; Park, I.S.; Kim, K.J.; Gawlik, K. A hydrogen-compression system using porous metal hydride pellets of LaNi ${ }_{5}-\mathrm{xAlx}$. Int. J. Hydrog. Energy 2008, 33, 870-877. [CrossRef]

29. Simičić, M.V.; Zdujić, M.; Jelovac, D.M.; Rakin, P.M. Hydrogen storage material based on $\mathrm{LaNi}_{5}$ alloy produced by mechanical alloying. J. Power Sources 2001, 92, 250-254. [CrossRef]

30. Van Mal, H.H.; Buschow, K.H.; Kuijpers, F.A. Hydrogen absorption and magnetic properties of LaCo ${ }_{5} \mathrm{Ni}_{5-5 x}$ compounds. J. Less Common Met. 1973, 32, 289-296. [CrossRef]

31. Sakai, T.; Oguro, K.; Miyamura, H.; Kuriyama, N.; Kato, A.; Ishikawa, H.; Iwakura, C. Some factors affecting the cycle lives of $\mathrm{LaNi}_{5}$-based alloy electrodes of hydrogen batteries. J. Less Common Met. 1990, 161, 193-202. [CrossRef] 
32. Kadir, K.; Sakai, T.; Uehara, I. Synthesis and structure determination of a new series of hydrogen storage alloys; $\mathrm{RMg}_{2} \mathrm{Ni}_{9}(\mathrm{R}=$ $\mathrm{La}, \mathrm{Ce}, \mathrm{Pr}, \mathrm{Nd}, \mathrm{Sm}$ and $\mathrm{Gd}$ ) built from $\mathrm{MgNi}_{2}$ Laves-type layers alternating with AB5 layers. J. Alloys Compd. 1997, 257, 115-121. [CrossRef]

33. Libowitz, G.G.; Hayes, H.F.; Gibb, T.R. The system zirconium-nickel and hydrogen. J. Phys. Chem. 1958, 62, 76-79. [CrossRef]

34. Hoang, K.; Van De Walle, C.G. Mechanism for the decomposition of lithium borohydride. Int. J. Hydrog. Energy 2012, 37, 5825-5832. [CrossRef]

35. Lal, C.; Jain, I.P. Effect of ball milling on structural and hydrogen storage properties of Mg-x wt $\%$ FeTi( $(x=2$ \& 5) solid solutions. Int. J. Hydrog. Energy 2012, 37, 3761-3766. [CrossRef]

36. Tessier, P.; Schulz, R.; Ström-Olsen, J.O. Elastic stress in composite FeTi hydrogen storage materials. J. Mater. Res. 1998, 13, 1538-1547. [CrossRef]

37. Aymard, L.; Lenain, C.; Courvoisier, L.; Salver-Disma, F.; Tarascon, J. Effect of Carbon Additives on the Electrochemical Properties of AB 5 Graphite Composite Electrodes Prepared by Mechanical Milling. J. Electrochem. Soc. 1999, 146, 2015. [CrossRef]

38. Jianfeng Zhang.; Zhinian Li.; Yuanfang Wu.; Xiumei Guo.; Jianhua Ye.; Baolong Yuan.; Shumao Wang.; Lijun Jiang. Recent advances on the thermal destabilization of Mg-based hydrogen storage materials. RSC Adv. 2019, 9, 408-428. [CrossRef]

39. Yartys, V.A.; Lototskyy, M.V.; Akiba, E.; Albert, R.; Antonov, V.E.; Ares, J.R.; Baricco, M.; Bourgeois, N.; Buckley, C.E.; Bellosta von Colbe, J.M.; et al. Magnesium based materials for hydrogen based energy storage: Past, present and future. Int. J. Hydrog. Energy 2019, 44, 7809-7859. [CrossRef]

40. Baran, A.; Materials, M.P. Magnesium-based materials for hydrogen storage-A scope review. Materials 2020, 13, 3993 . [CrossRef]

41. Ivanov, E.; Konstanchuk, I.; Stepanov, A.; Boldyrev, V. Magnesium mechanical alloys for hydrogen storage. J. Less Common Met. 1987, 131, 25-29. [CrossRef]

42. Singh, A.K.; Singh, A.K.; Srivastava, O.N. On the synthesis of the $\mathrm{Mg}_{2} \mathrm{Ni}$ alloy by mechanical alloying. J. Alloys Compd. 1995, 227, 63-68. [CrossRef]

43. Zaluski, L.; Zaluska, A.; Ström-Olsen, J.O. Hydrogen absorption in nanocrystalline $\mathrm{Mg}_{2} \mathrm{Ni}$ formed by mechanical alloying. J. Alloys Compd. 1995, 217, 245-249. [CrossRef]

44. Orimo, S.; Fujii, H. Materials science of Mg-Ni-based new hydrides. Appl. Phys. A 2001, 72, 167-186. [CrossRef]

45. Sakintuna, B.; Lamari-Darkrim, F.; Hirscher, M. Metal hydride materials for solid hydrogen storage: A review. Int. J. Hydrog. Energy 2007, 32, 1121-1140. [CrossRef]

46. Cui, N.; He, P.; Luo, J.L. Magnesium-based hydrogen storage materials modified by mechanical alloying. Acta Mater. 1999, 47, 3737-3743. [CrossRef]

47. Liang, G.; Boily, S.; Huot, J.; Van Neste, A.; Schulz, R. Mechanical alloying and hydrogen absorption properties of the Mg-Ni system. J. Alloys Compd. 1998, 267, 302-306. [CrossRef]

48. Huang, L.W.; Elkedim, O.; Moutarlier, V. Synthesis and characterization of nanocrystalline $\mathrm{Mg}_{2} \mathrm{Ni}$ prepared by mechanical alloying: Effects of substitution of Mn for Ni. J. Alloys Compd. 2010, 504, S311-S314. [CrossRef]

49. Huang, L.W.; Elkedim, O.; Hamzaoui, R. First principles investigation of the substitutional doping of $\mathrm{Mn}$ in $\mathrm{Mg}_{2} \mathrm{Ni}$ phase and the electronic structure of $\mathrm{Mg}_{3} \mathrm{MnNi}_{2}$ phase. J. Alloys Compd. 2011, 509, S328-S333. [CrossRef]

50. Du, Q.; Li, S.; Huang, G.; Feng, Q. Enhanced electrochemical kinetics of magnesium-based hydrogen storage alloy by mechanical milling with graphite. Int. J. Hydrog. Energy 2017, 42, 21871-21879. [CrossRef]

51. Gkanas, E.I.; Damian, A.; Ioannidou, A.; Stoian, G.; Lupu, N.; Gjoka, M.; Makridis, S.S. Synthesis, characterisation and hydrogen sorption properties of mechanically alloyed $\mathrm{Mg}\left(\mathrm{Ni}_{1-\mathrm{x}} \mathrm{Mn}_{\mathrm{x}}\right)_{2}$. Mater. Today Energy 2019, 13, 186-194. [CrossRef]

52. Ruggeri, S.; Lenain, C.; Roué, L.; Alamdari, H.; Liang, G.X.; Huot, J.; Schulz, R. Optimization of the Ball-Milling Parameters for the Synthesis of Amorphous MgNi Alloy Used as Negative Electrode in Ni-MH Batteries. Mater. Sci. Forum 2001, 377, 63-70. [CrossRef]

53. Liu, W.; Lei, Y.; Sun, D.; Wu, J.; Wang, Q. A study of the degradation of the electrochemical capacity of amorphous $\mathrm{Mg}_{50} \mathrm{Ni}_{50}$ alloy. J. Power Sources 1996, 58, 243-247. [CrossRef]

54. Goo, N.H.; Woo, J.H.; Lee, K.S. Mechanism of rapid degradation of nanostructured $\mathrm{Mg}_{2} \mathrm{Ni}$ hydrogen storage alloy electrode synthesized by mechanical alloying and the effect of mechanically coating with nickel. J. Alloys Compd. 1999, 288, $286-293$. [CrossRef]

55. Lenain, C.; Aymard, L.; Electrochemistry, J.T.J.S.S. Electrochemical properties of $\mathrm{Mg}_{2} \mathrm{Ni}$ and $\mathrm{Mg}_{2} \mathrm{Ni}_{2}$ prepared by mechanical alloying. Electrochemistry 1998, 2, 285-290.

56. Abe, T.; Tachikawa, T.; Hatano, Y.; Watanabe, K. Electrochemical behavior of amorphous MgNi as negative electrodes in rechargeable Ni-MH batteries. J. Alloys Compd. 2002, 330-332, 792-795. [CrossRef]

57. Anik, M. Electrochemical hydrogen storage capacities of $\mathrm{Mg}_{2} \mathrm{Ni}$ and $\mathrm{MgNi}$ alloys synthesized by mechanical alloying. J. Alloys Compd. 2010, 491, 565-570. [CrossRef]

58. Iwakura, C.; Shin-ya, R.; Miyanohara, K.; Nohara, S.; Inoue, H. Effects of Ti-V substitution on electrochemical and structural characteristics of MgNi alloy prepared by mechanical alloying. Electrochim. Acta 2001, 46, 2781-2786. [CrossRef]

59. Ruggeri, S.; Roué, L.; Huot, J.; Schulz, R.; Aymard, L.; Tarascon, J.M. Properties of mechanically alloyed Mg-Ni-Ti ternary hydrogen storage alloys for Ni-MH batteries. J. Power Sources 2002, 112, 547-556. [CrossRef]

60. Jiang, J.J.; Gasik, M. An electrochemical investigation of mechanical alloying of MgNi-based hydrogen storage alloys. J. Power Sources 2000, 89, 117-124. [CrossRef] 
61. Elkedim, O.; Huang, L.; Bassir, D. Advanced study of hydrogen storage by substitutional doping of $\mathrm{Mn}$ and $\mathrm{Ti}$ in $\mathrm{Mg}{ }_{2} \mathrm{Ni}$ phase. Int. J. Simul. Multidiscip. Des. Optim. 2014, 5, A24. [CrossRef]

62. Amirkhiz, B.S.; Danaie, M.; Mitlin, D. The influence of SWCNT-metallic nanoparticle mixtures on the desorption properties of milled $\mathrm{MgH}_{2}$ powders. Nanotechnology 2009, 20, 204016. [CrossRef]

63. Yao, X.; Wu, C.; Du, A.; Lu, G.Q.; Cheng, H.; Smith, S.C.; Zou, J. Mg-Based Nanocomposites with High Capacity and Fast Kinetics for Hydrogen Storage. J. Phys. Chem. B 2006, 110, 11697-11703. [CrossRef]

64. Huang, L.W.; Elkedim, O.; Nowak, M.; Jurczyk, M.; Chassagnon, R.; Meng, D.W. Synergistic effects of multiwalled carbon nanotubes and $\mathrm{Al}$ on the electrochemical hydrogen storage properties of $\mathrm{Mg}_{2} \mathrm{Ni}$-type alloy prepared by mechanical alloying. Int J. Hydrog. Energy 2012, 37, 1538-1545. [CrossRef]

65. Guo, J.; Yang, K.; Xu, L.; Liu, Y.; Zhou, K. Hydrogen storage properties of $\mathrm{Mg}_{76} \mathrm{Ti1}_{2} \mathrm{Fe}_{12-\mathrm{x}} \mathrm{Nix}(\mathrm{x}=0,4,8,12)$ alloys by mechanical alloying. Int. J. Hydrog. Energy 2007, 32, 2412-2416. [CrossRef]

66. Gao, X. P.; Wang, Y.; Lu, Z.W.; Hu, W. K.; Wu, F.; Song, D.Y.; Shen, P.W. Preparation and Electrochemical Hydrogen Storage of the Nanocrystalline $\mathrm{LaMg}_{12}$ Alloy with Ni Powders. Chem. Mater. 2004, 16, 2515-2517. [CrossRef]

67. Zhang, Y.; Wang, J.; Zhang, P.; Zhu, Y.; Hou, Z.; Shang, H. An Investigation on Hydrogen Storage Kinetics of the Nanocrystalline and Amorphous LaMg 12 -type Alloys Synthesized by Mechanical Milling. J. Wuhan Univ. Technol.-Mater. Sci. Ed. 2018, 33, 278-287. [CrossRef]

68. Li, X.; Zhao, D.; Zhang, Y.; Xu, J.; Zhang, G.; Zhang, Y. Hydrogen storage properties of mechanically milled $\mathrm{La}_{2} \mathrm{Mg}_{17-\mathrm{x}}$ wt. $(\mathrm{x}=0$, 50, 100, 150 and 200) composites. J. Rare Earths 2013, 31, 694-700. [CrossRef]

69. Song, M.Y. Improvement in hydrogen storage characteristics of magnesium by mechanical alloying with nickel. J. Mater. Sci. 1995, 30, 1343-1351. [CrossRef]

70. Lotoskyy, M.; Denys, R.; Yartys, V.A.; Eriksen, J.; Goh, J.; Nyamsi, S.N.; Sita, C.; Cummings, F. An outstanding effect of graphite in nano- $\mathrm{MgH}_{2}-\mathrm{TiH}_{2}$ on hydrogen storage performance. J. Mater. Chem. A 2018, 6, 10740-10754. [CrossRef]

71. Zhou, C.; Fang, Z.Z.; Robert C. Bowman, J. Stability of Catalyzed Magnesium Hydride Nanocrystalline During Hydrogen Cycling. Part I: Kinetic Analysis. J. Phys. Chem. C 2015, 119, 22261-22271. [CrossRef]

72. Rizo-Acosta, P.; Cuevas, F.; Latroche, M. Hydrides of early transition metals as catalysts and grain growth inhibitors for enhanced reversible hydrogen storage in nanostructured magnesium. J. Mater. Chem. A 2019, 7, 23064-23075. [CrossRef]

73. Chiang, C.H.; Chin, Z.H.; Perng, T.P. Hydrogenation of TiFe by high-energy ball milling. J. Alloys Compd. 2000, 307, 259-265. [CrossRef]

74. Emami, H.; Edalati, K.; Matsuda, J.; Akiba, E.; Horita, Z. Hydrogen storage performance of TiFe after processing by ball milling Acta Mater. 2015, 88, 190-195. [CrossRef]

75. Zaluski, L.; Zaluska, A.; Ström-Olsen, J.O. Nanocrystalline metal hydrides. J. Alloys Compd. 1997, 253-254, 70-79. [CrossRef]

76. Zadorozhnyi, V.Y.; Skakov, Y.A.; Milovzorov, G.S. Appearance of metastable states in Fe-Ti and Ni-Ti systems in the process of mechanochemical synthesis. Met. Sci. Heat Treat. 2008, 50, 404-410. [CrossRef]

77. Zadorozhnyy, V.; Klyamkin, S.; Zadorozhnyy, M.; Bermesheva, O.; Kaloshkin, S. Hydrogen storage nanocrystalline TiFe intermetallic compound: Synthesis by mechanical alloying and compacting. Int. J. Hydrog. Energy 2012, 37, 17131-17136. [CrossRef]

78. Inui, H.; Yamamoto, T.; Hirota, M.; Yamaguchi, M. Lattice defects introduced during hydrogen absorption-desorption cycles and their effects on P-C characteristics in some intermetallic compounds. J. Alloys Compd. 2002, 330-332, 117-124. [CrossRef]

79. Zadorozhnyy, V.Y.; Klyamkin, S.N.; Zadorozhnyy, M.Y.; Gorshenkov, M.V.; Kaloshkin, S.D. Mechanical alloying of nanocrystalline intermetallic compound TiFe doped with sulfur and magnesium. J. Alloys Compd. 2014, 615, S569-S572. [CrossRef]

80. Berdonosova, E.A.; Zadorozhnyy, V.Y.; Zadorozhnyy, M.Y.; Geodakian, K.V.; Zheleznyi, M.V.; Tsarkov, A.A.; Kaloshkin, S.D.; Klyamkin, S.N. Hydrogen storage properties of TiFe-based ternary mechanical alloys with cobalt and niobium. A thermochemical approach. Int. J. Hydrog. Energy 2019, 44, 29159-29165. [CrossRef]

81. Zadorozhnyy, V.Y.; Klyamkin, S.N.; Zadorozhnyy, M.Y.; Bermesheva, O.V.; Kaloshkin, S.D. Mechanical alloying of nanocrystalline intermetallic compound TiFe doped by aluminum and chromium. J. Alloys Compd. 2014, 586, S56-S60. [CrossRef]

82. Liang, L.; Wang, F.; Rong, M.; Wang, Z.; Yang, S.; Wang, J.; Zhou, H.; Liang, L.; Wang, F.; Rong, M.; et al. Recent Advances on Preparation Method of Ti-Based Hydrogen Storage Alloy. J. Mater. Sci. Chem. Eng. 2020, 8, 18-38. [CrossRef]

83. Sujan, G.K.; Pan, Z.; Li, H.; Liang, D.; Alam, N. An overview on TiFe intermetallic for solid-state hydrogen storage: microstructure, hydrogenation and fabrication processes. Crit. Rev. Solid State Mater. Sci. 2019, 45, 410-427. [CrossRef]

84. Falcão, R.B.; Dammann, E.D.; Rocha, C.J.; Durazzo, M.; Ichikawa, R.U.; Martinez, L.G.; Botta, W.J.; Leal Neto, R.M. An alternative route to produce easily activated nanocrystalline TiFe powder. Int. J. Hydrog. Energy 2018, 43, 16107-16116. [CrossRef]

85. Nobuki, T.; Crivello, J.C.; Cuevas, F.; Joubert, J.M. Fast synthesis of TiNi by mechanical alloying and its hydrogenation properties. Int. J. Hydrog. Energy 2019, 44, 10770-10776. [CrossRef]

86. Zhang, Z.; Elkedim, O.; Balcerzak, M.; Jurczyk, M. Structural and electrochemical hydrogen storage properties of MgTiNix $(\mathrm{x}=$ $0.1,0.5,1,2)$ alloys prepared by ball milling. Int. J. Hydrog. Energy 2016, 41, 11761-11766. [CrossRef]

87. Zhang, Z.; Elkedim, O.; Ma, Y.Z.; Balcerzak, M.; Jurczyk, M. The phase transformation and electrochemical properties of TiNi alloys with Cu substitution: Experiments and first-principle calculations. Int. J. Hydrog. Energy 2017, 42, 1444-1450. [CrossRef]

88. Zhang, Z.; Elkedim, O.; Balcerzak, M.; Jurczyk, M.; Chassagnon, R. Effect of Ni content on the structure and hydrogenation property of mechanically alloyed TiMgNix ternary alloys. Int. J. Hydrog. Energy 2017, 42, 23751-23758. [CrossRef] 
89. Zhang, Z.; Elkedim, O.; Zhang, M.; Bassir, D. Systematic investigation of mechanically alloyed Ti-Mg-Ni used as negative electrode in Ni-MH battery. J. Solid State Electrochem. 2017, 22, 1669-1676. [CrossRef]

90. Li, X.D.; Elkedim, O.; Cuevas, F.; Chassagnon, R. Structural and hydrogenation study on the ball milled $\mathrm{TiH}_{2}-\mathrm{Mg}-\mathrm{Ni}$. Int. J. Hydrog. Energy 2015, 40, 4212-4218. [CrossRef]

91. Li, X.D.; Elkedim, O.; Nowak, M.; Jurczyk, M. Characterization and first principle study of ball milled Ti-Ni with Mg doping as hydrogen storage alloy. Int. J. Hydrog. Energy 2014, 39, 9735-9743. [CrossRef]

92. Hosni, B.; Li, X.; Khaldi, C.; Elkedim, O.; Lamloumi, J. Structure and electrochemical hydrogen storage properties of Ti2Ni alloy synthesized by ball milling. J. Alloys Compd. 2014, 615, 119-125. [CrossRef]

93. Li, X.D.; Elkedim, O.; Nowak, M.; Jurczyk, M.; Chassagnon, R. Structural characterization and electrochemical hydrogen storage properties of Ti2-xZrxNi $(x=0,0.1,0.2)$ alloys prepared by mechanical alloying. Int. J. Hydrog. Energy 2013, 38, 12126-12132. [CrossRef]

94. Chu, H.; Zhang, Y.; Sun, L.; Qiu, S.; Qi, Y.; Xu, F.; Yuan, H. Structure and electrochemical properties of composite electrodes synthesized by mechanical milling Ni-free TiMn 2 -based alloy with La-based alloys. J. Alloys Compd. 2007, 446-447, 614-619. [CrossRef]

95. Choi, M.J.; Hong, H.S.; Lee, K.S. Electrochemical characteristics of the composite metal hydride of TiFe and TiMn 2 synthesized by mechanical alloying. J. Alloys Compd. 2003, 358, 306-311. [CrossRef]

96. Liang, G.; Huot, J.; Schulz, R. Hydrogen storage properties of the mechanically alloyed LaNi5-based materials. J. Alloys Compd. 2001, 320, 133-139. [CrossRef]

97. Lototsky, M.V.; Williams, M.; Yartys, V.A.; Klochko, Y.V.; Linkov, V.M. Surface-modified advanced hydrogen storage alloys for hydrogen separation and purification. J. Alloys Compd. 2011, 509, S555-S561. [CrossRef]

98. Bratanich, T.I.; Skorokhod, V.V. Reversible Hydriding of $\mathrm{LaNi}_{5-\mathrm{x}} \mathrm{Al}_{\mathrm{x}}-\mathrm{Pd}$ Composites in the Presence of Carbon Monoxide. Powder Metall. Met. Ceram. 2000, 39, 575-583. [CrossRef]

99. Modibane, K.D.; Lototskyy, M.; Davids, M.W.; Williams, M.; Hato, M.J.; Molapo, K.M. Influence of co-milling with palladium black on hydrogen sorption performance and poisoning tolerance of surface modified AB5-type hydrogen storage alloy. J. Alloys Compd. 2018, 750, 523-529. [CrossRef]

100. Kadir, K.; Sakai, T.; Uehara, I. Structural investigation and hydrogen storage capacity of $\mathrm{LaMg}_{2} \mathrm{Ni}_{9}$ and $\left(\mathrm{La}_{0.65} \mathrm{Ca}_{0.35}\right)\left(\mathrm{Mg}_{1.32} \mathrm{Ca}_{0.68}\right) \mathrm{Ni}_{9}$ of the AB2C9 type structure. J. Alloys Compd. 2000, 302, 112-117. [CrossRef]

101. Liu, W.; Webb, C.J.; Gray, E.M.A. Review of hydrogen storage in AB3 alloys targeting stationary fuel cell applications. Int. J. Hydrog. Energy 2016, 41, 3485-3507. [CrossRef]

102. Belgacem, Y.B.; Khaldi, C.; Lamloumi, J. The effect of the discharge rate on the electrochemical properties of AB3-type hydrogen storage alloy as anode in nickel-metal hydride batteries. Int. J. Hydrog. Energy 2017, 42, 12797-12807. [CrossRef]

103. Fang, F.; Chen, Z.; Wu, D.; Liu, H.; Dong, C.; Song, Y.; Sun, D. Subunit volume control mechanism for dehydrogenation performance of AB3-type superlattice intermetallics. J. Power Sources 2019, 427, 145-153. [CrossRef]

104. Jaafar, H.; Aymard, L.; Dachraoui, W.; Demortière, A.; Abdellaoui, M. Preparation and characterization of mechanically alloyed $\mathrm{AB}_{3}$-type based material $\mathrm{LaMg}_{2} \mathrm{Ni}_{5} \mathrm{~A}_{14}$ and its solid-gaz hydrogen storage reaction. J. Solid State Chem. 2018, 260, 73-79. [CrossRef]

105. Elghali, M.; Abdellaoui, M.; Paul-Boncour, V.; Latroche, M. Synthesis and structural characterization of mechanically alloyed $\mathrm{AB}_{3}$-type based material: $\mathrm{LaZr}_{2} \mathrm{Mn}_{4} \mathrm{Ni}_{5}$. Intermetallics 2013, 41, 76-81. [CrossRef]

106. Ayari, M.; Ghodbane, O.; Abdellaoui, M. Elaboration and electrochemical characterization of $\mathrm{LaTi}_{2} \mathrm{Cr}_{4} \mathrm{Ni}_{5}-$ based metal hydride alloys. Int. J. Hydrog. Energy 2015, 40, 10934-10942. [CrossRef]

107. Sahli, I.; Ghodbane, O.; Abdellaoui, M. Elaboration and electrochemical characterization of $\mathrm{LaZr}_{2} \mathrm{Cr}_{4} \mathrm{Ni}_{5}-$ based metal hydride alloys. Ionics 2016, 22, 1973-1983. [CrossRef]

108. Ayari, M.; Ghodbane, O.; Abdellaoui, M. Electrochemical study of the reversible hydrogen storage in CeTi2Cr4Ni5-based metal hydride alloys. Int. J. Hydrog. Energy 2016, 41, 18582-18591. [CrossRef]

109. Kadir, K.; Kuriyama, N.; Sakai, T.; Uehara, I.; Eriksson, L. Structural investigation and hydrogen capacity of CaMg $\mathrm{Ni}_{9}$ : $\mathrm{A}$ new phase in the $\mathrm{AB}_{2} \mathrm{C}_{9}$ system isostructural with $\mathrm{LaMg}_{2} \mathrm{Ni}_{9}$. J. Alloys Compd. 1999, 284, 145-154. [CrossRef]

110. Miraglia, S.; Girard, G.; Fruchart, D.; Liang, G.; Huot, J.; Schulz, R. Structural characterization and some hydrogen absorption properties of (MgxCa1-x)Ni2.6: A new phase in the Mg-Ca-Ni system. J. Alloys Compd. 2009, 478, L33-L36. [CrossRef]

111. Chebab, S.; Abdellaoui, M.; Latroche, M.; Paul-Boncour, V. Structural and hydrogen storage properties of LaCaMgNig-type alloy obtained by mechanical alloying. Mater. Renew. Sustain. Energy 2015, 4, 1-10. [CrossRef]

112. Akiba, E.; Hayakawa, H.; Kohno, T. Crystal structures of novel La-Mg-Ni hydrogen absorbing alloys. J. Alloys Compd. 2006, 408-412, 280-283. [CrossRef]

113. Szajek, A.; Jurczyk, M.; Rajewski, W. The electronic and electrochemical properties of the $\mathrm{LaNi}_{5}, \mathrm{LaNi} 4 \mathrm{Al}$ and $\mathrm{LaNi3} \mathrm{AlCo}$ systems. J. Alloys Compd. 2000, 307, 290-296. [CrossRef]

114. Balcerzak, M.; Nowak, M.; Jurczyk, M. Hydrogenation and electrochemical studies of La-Mg-Ni alloys. Int. J. Hydrog. Energy 2017, 42, 1436-1443. [CrossRef]

115. Balcerzak, M.; Nowak, M.; Jurczyk, M. The Influence of Pr and Nd Substitution on Hydrogen Storage Properties of Mechanically Alloyed (La,Mg) ${ }_{2} \mathrm{Ni}_{7}$-Type Alloys. J. Mater. Eng. Perform. 2018, 27, 6166-6174. [CrossRef] 
116. Dymek, M.; Nowak, M.; Jurczyk, M.; Bala, H. Electrochemical characterization of nanocrystalline hydrogen storage $\mathrm{La}_{1.5} \mathrm{Mg}_{0.5} \mathrm{Ni}_{6.5} \mathrm{Co}_{0.5}$ alloy covered with amorphous nickel. J. Alloys Compd. 2019, 780, 697-704. [CrossRef]

117. Nowak, M.; Balcerzak, M.; Jurczyk, M. Effect of Substitutional Elements on the Thermodynamic and Electrochemical Properties of Mechanically Alloyed La1.5Mg0.5Ni7-xMx alloys $(\mathrm{M}=\mathrm{Al}, \mathrm{Mn})$. Metals 2020, 10, 578. [CrossRef]

118. Hu, Y.Q.; Zhang, H.F.; Yan, C.; Ye, L.; Ding, B.Z.; Hu, Z.Q. Preparation and hydrogenation of body-centered-cubic TiCr2 alloy. Mater. Lett. 2004, 58, 783-786. [CrossRef]

119. Takeichi, N.; Takeshita, H.T.; Oishi, T.; Kaneko, T.; Tanaka, H.; Kiyobayashi, T.; Kuriyama, N. Hydrogenation of Body-CenteredCubic Titanium-Chromium Alloys Prepared by Mechanical Grinding. Mater. Trans. 2002, 43, 2161-2164. [CrossRef]

120. Balcerzak, M. Hydrogenation properties of nanocrystalline TiVMn body-centered-cubic alloys. Int. J. Hydrog. Energy 2020, 45, 15521-15529. [CrossRef]

121. Lototsky, M.V.; Yartys, V.A.; Zavaliy, I.Y. Vanadium-based BCC alloys: Phase-structural characteristics and hydrogen sorption properties. J. Alloys Compd. 2005, 404-406, 421-426. [CrossRef]

122. Balcerzak, M. Effect of $\mathrm{Ni}$ on electrochemical and hydrogen storage properties of V-rich body-centered-cubic solid solution alloys. Int. J. Hydrog. Energy 2018, 43, 8395-8403. [CrossRef]

123. Balcerzak, M. Structural, Electrochemical and Hydrogen Sorption Studies of Nanocrystalline Ti-V-Co and Ti-V-Ni-Co Alloys Synthesized by Mechanical Alloying Method. J. Mater. Eng. Perform. 2019, 28, 4838-4844. [CrossRef]

124. Kondo, T.; Sakurai, Y. Hydrogen absorption-desorption properties of $\mathrm{Mg}-\mathrm{Ca}-\mathrm{V}$ BCC alloy prepared by mechanical alloying. $J$. Alloys Compd. 2006, 417, 164-168. [CrossRef]

125. Shao, H.; Asano, K.; Enoki, H.; Akiba, E. Correlation study between hydrogen absorption property and lattice structure of Mg-based BCC alloys. Int. J. Hydrog. Energy 2009, 34, 2312-2318. [CrossRef]

126. Djellouli, A.; Benyelloul, K.; Aourag, H.; Bekhechi, S.; Adjadj, A.; Bouhadda, Y.; ElKedim, O. A datamining approach to classify, select and predict the formation enthalpy for intermetallic compound hydrides. Int. J. Hydrog. Energy 2018, 43, 19111-19120. [CrossRef]

127. Zhang, Y.; Zhang, H.; Ding, X.; Liu, D.; Zhang, Q.; Si, T. Microstructure characterization and hydrogen storage properties study of $\mathrm{Mg}_{2} \mathrm{Ni}_{0.92} \mathrm{M}_{0.08}(\mathrm{M}=\mathrm{Ti}, \mathrm{V}, \mathrm{Fe}$ or Si) alloys. Prog. Nat. Sci. Mater. Int. 2018, 28, 464-469. [CrossRef]

128. Hapçı Ağaoğlu, G.; Orhan, G. Elaboration and electrochemical characterization of Mg-Ni hydrogen storage alloy electrodes for $\mathrm{Ni} / \mathrm{MH}$ batteries. Int. J. Hydrog. Energy 2017, 42, 8098-8108. [CrossRef]

129. Kumar, S.; Miyaoka, H.; Ichikawa, T.; Dey, G.K.; Kojima, Y. Micro-alloyed $\mathrm{Mg}_{2} \mathrm{Ni}$ for better performance as negative electrode of Ni-MH battery and hydrogen storage. Int. J. Hydrog. Energy 2017, 42, 5220-5226. [CrossRef]

130. Nobuki, T.; Okuzumi, Y.; Hatate, M.; Crivello, J.C.; Cuevas, F.; Joubert, J.M. Mechanosynthesis and Reversible Hydrogen Storage of $\mathrm{Mg}_{2} \mathrm{Ni}$ and $\mathrm{Mg}_{2} \mathrm{Cu}$ Alloys. Mater. Trans. 2019, 60, 441-449. [CrossRef]

131. Chen, X.; Zou, J.; Huang, S.; He, G.; Zhao, N.; Zeng, X.; Ding, W. Hydrogen storage in $\mathrm{Mg}_{2} \mathrm{Ni}(\mathrm{Fe}) \mathrm{H}_{4}$ nano particles synthesized from coarse-grained $\mathrm{Mg}$ and nano sized $\mathrm{Ni}(\mathrm{Fe})$ precursor. RSC Adv. 2018, 8, 18959-18965. [CrossRef]

132. Grigorova, E.; Tzvetkov, P.; Todorova, S.; Markov, P.; Spassov, T. Facilitated Synthesis of $\mathrm{Mg}_{2} \mathrm{Ni}$ Based Composites with Attractive Hydrogen Sorption Properties. Materials 2021, 14, 1936. [CrossRef] [PubMed]

133. Si, T.; Ma, Y.; Li, Y.; Liu, D. Solid solution of $\mathrm{Cu}$ in $\mathrm{Mg}_{2} \mathrm{NiH}_{4}$ and its destabilized effect on hydrogen desorption. Mater. Chem. Phys. 2017, 193, 1-6. [CrossRef]

134. Hou, J.; Liu, Z.; Zhu, Y.; Fei, J.; Song, Y.; Zhang, Y.; Zhang, J.; Liu, Y.; Chen, Q.; Li, L. Electrochemical hydrogen storage performance of $\mathrm{Mg}_{3} \mathrm{GeNi}_{2}$ alloy. Intermetallics 2020, 127, 106961. [CrossRef]

135. Abrashev, B.; Spassov, T.; Pandev, M.; Vassilev, S.; Popov, A. Hydrogen sorption and electrochemical properties of Ti-Fe based alloys synthesized by mechanical alloying. Bulg. Chem. Commun. 2017, 49, 247-253.

136. Zadorozhnyy, V.; Berdonosova, E.; Gammer, C.; Eckert, J.; Zadorozhnyy, M.; Bazlov, A.; Zheleznyi, M.; Kaloshkin, S.; Klyamkin, S. Mechanochemical synthesis and hydrogenation behavior of (TiFe) ${ }_{100-x} \mathrm{Ni}_{\mathrm{x}}$ alloys. J. Alloys Compd. 2019, 796, 42-46. [CrossRef]

137. Nobuki, T.; Moriya, T.; Hatate, M.; Crivello, J.C.; Cuevas, F.; Joubert, J.M. Synthesis of tife hydrogen absorbing alloys prepared by mechanical alloying and SPS treatment. Metals 2018, 8, 264. [CrossRef]

138. Manna, J.; Tougas, B.; Huot, J. Mechanical activation of air exposed TiFe +4 wthydrogenation by cold rolling and ball milling. Int. J. Hydrog. Energy 2018, 43, 20795-20800. [CrossRef]

139. Shang, H.; Zhang, Y.; Li, Y.; Qi, Y.; Guo, S.; Zhao, D. Investigation on gaseous and electrochemical hydrogen storage performances of as-cast and milled $\mathrm{Ti}_{1.1} \mathrm{Fe}_{0.9} \mathrm{Ni}_{0.1}$ and $\mathrm{Ti}_{1.09} \mathrm{Mg}_{0.01} \mathrm{Fe}_{0.9} \mathrm{Ni}_{0.1}$ alloys. Int. J. Hydrog. Energy 2018, 43, 1691-1701. [CrossRef]

140. Romero, G.; Lv, P.; Huot, J. Effect of ball milling on the first hydrogenation of TiFe alloy doped with $4 \mathrm{wt} \%$ ( $\mathrm{Zr}+2 \mathrm{Mn})$ additive. J. Mater. Sci. 2018, 53, 13751-13757. [CrossRef]

141. Gkanas, E.I.; Khzouz, M.; Donac, A.; Ioannidou, A.; Stoian, G.; Lupu, N.; Gjoka, M.; Makridis, S.S. Synthesis and Hydrogen Sorption Characteristics of Mechanically Alloyed $\mathrm{Mg}\left(\mathrm{Ni}_{\mathrm{x}} \mathrm{Mn}_{1-\mathrm{x}}\right)_{2}$ Intermetallics. arXiv 2017, arXiv:1702.04807.

142. Wang, Z.M.; Zhou, H.Y.; Gu, Z.F.; Cheng, G.; Yu, A.B. Preparation of LaMgNi4 alloy and its electrode properties. J. Alloys Compd. 2004, 377, L7-L9. [CrossRef]

143. Humana, R.M.; Ruiz, F.C.; Thomas, J.E.; Peretti, H.A.; Castro, E.B.; Visintin, A. Properties of composites of metal hydride alloys synthesized by mechanical milling. J. Solid State Electrochem. 2016, 21, 153-160. [CrossRef]

144. M, E.; M, A. Structural and Hydriding Properties of the $\mathrm{LaZr}_{2} \mathrm{Mn}_{4} \mathrm{Ni}_{5}-\mathrm{AB} 3$ Type Based Alloy Prepared by Mechanical Alloying from the $\mathrm{LaNi}_{5}$ and $\mathrm{ZrMn}_{2}$ Binary Compounds. J. Mater. Sci. Eng. 2016, 05. [CrossRef] 
145. Jaafar, H.; Dhiab, A.; Slama, C.; Sahli, I.; Abdellaoui, M. Synthesis of quaternary nano-intermetallic $\mathrm{LaTi}_{2} \mathrm{Ni}_{5} \mathrm{Al}_{4}$ with its hydrogen encapsulation and inspection using lithium-hydride cell. Micro Nano Lett. 2020, 15, 201-205. [CrossRef]

146. Chebab, S.; Abdellaoui, M.; Latroche, M.; Paul-Boncour, V. Electrochemical characterization of mechanically alloyed LaCaMgNig compound. Mater. Renew. Sustain. Energy 2016, 5, 1-7. [CrossRef]

147. Ayari, M.; Sahli, I.; Elghali, M.; Ghodbane, O.; Jaafar, H.; Abdellaoui, M. Synthesis and characterizations of structural and electrochemical properties of $\mathrm{CeTi}_{2} \mathrm{Ni}_{4.5} \mathrm{Al}_{0.2} \mathrm{Mn}_{0.3} \mathrm{Cr}_{4} \mathrm{AB}_{3}$ type compound. J. Alloys Compd. 2021, 884, 161017. [CrossRef]

148. Nowak, M.; Balcerzak, M.; Jurczyk, M. Hydrogen storage and electrochemical properties of mechanically alloyed $\mathrm{La}_{1.5-\mathrm{x}} \mathrm{Gd}_{\mathrm{x}} \mathrm{Mg}_{0.5} \mathrm{Ni}_{7}(0 \leq \mathrm{x} \leq 1.5)$. Int. J. Hydrog. Energy 2018, 43, 8897-8906. [CrossRef]

149. Dymek, M.; Nowak, M.; Jurczyk, M.; Bala, H. Encapsulation of $\mathrm{La}_{1.5} \mathrm{Mg}_{0.5} \mathrm{Ni}_{7}$ nanocrystalline hydrogen storage alloy with Ni coatings and its electrochemical characterization. J. Alloys Compd. 2018, 749, 534-542. [CrossRef]

150. Dhaouadi, H.; Ajlani, H.; Zormati, H.; Abdellaoui, M. Elaboration and electrochemical characterization of two hydrogen storage alloy types: $\mathrm{LaNi}_{3-\mathrm{x}} \mathrm{Mn}_{\mathrm{x}} \mathrm{Cr}_{2}(\mathrm{x}=0,0.1$, and 0.3) and La2Ni7. Ionics 2018, 24, 2017-2027. [CrossRef]

151. Srivastava, S.; Panwar, K. Investigations on Microstructures of Ball-milled MmNi ${ }_{5}$ Hydrogen Storage Alloy. Mater. Res. Bull. 2016, 73, 284-289. [CrossRef]

152. Dabaki, Y.; Khaldi, C.; Fenineche, N.; ElKedim, O.; Tliha, M.; Lamloumi, J. Electrochemical Studies on the Ca-Based Hydrogen Storage Alloy for Different Milling Times. Met. Mater. Int. 2019, 27, 1005-1024. [CrossRef]

153. -ullah Rather, S.; Ullah Rather, S. Hydrogen uptake of mechanically milled lani 5-mwcnts nanocomposite. Artic. Int. J. Adv. Sci. Eng. Inf. Technol. 2018, 6, 2321-9009.

154. Li, J.; Li, B.; Yu, X.; Zhao, H.; Shao, H. Geometrical effect in Mg-based metastable nano alloys with BCC structure for hydrogen storage. Int. J. Hydrog. Energy 2019, 44, 29291-29296. [CrossRef]

155. Fujiwara, K.; Uehiro, R.; Edalati, K.; Li, H.W.; Floriano, R.; Akiba, E.; Horita, Z. New MgVCr BCC alloys synthesized by high-pressure torsion and ball milling. Mater. Trans. 2018, 59, 741-746. [CrossRef]

156. Balcerzak, M.; Wagstaffe, M.; Robles, R.; Pruneda, M.; Noei, H. Effect of Cr on the hydrogen storage and electronic properties of BCC alloys: Experimental and first-principles study. Int. J. Hydrog. Energy 2020, 45, 28996-29008. [CrossRef]

157. Zhan, Y.; Zhang, Y.; Zhu, Y. F.; Zhuang, X.Y.; Neng, W.A.N.; Yi, Q.U.; Guo, L.; Wang, M.; Li, Q. Electrochemical performances of $\mathrm{Mg}_{45} \mathrm{M}_{5} \mathrm{Co}_{50}(\mathrm{M}=\mathrm{Pd}, \mathrm{Zr})$ ternary hydrogen storage electrodes. Trans. Nonferrous Met. Soc. China 2016, 26, 1388-1395. [CrossRef]

158. de Araujo-Silva, R.; Neves, A.M.; Vega, L.E.; Triques, M.R.; Leiva, D.R.; Kiminami, C.S.; Ishikawa, T.T.; Jorge Junior, A.M.; Botta, W.J. Synthesis of $\beta$-Ti-Nb alloys from elemental powders by high-energy ball milling and their hydrogenation features. Int. J. Hydrog. Energy 2018, 43, 18382-18391. [CrossRef]

159. Kazemipour, M.; Salimijazi, H.; Arefarjmand, A.; Saidi, A.; Saatchi, A. Electrochemical Hydrogen Storage Capacity of $\mathrm{Ti}_{0.9} \mathrm{Zr}_{0.1} \mathrm{Mn}_{1.2} \mathrm{~V}_{0.4} \mathrm{Cr}_{0.4}$ Alloy Synthesized by Ball Milling and Annealing. Trans. Indian Inst. Met. 2015, 69, 1327-1333. [CrossRef] 